\title{
Revolving SEM images visualising 3D taxonomic characters: application to six species of the millipede genus Ommatoiulus Latzel, I 884, with description of seven new species and an interactive key to the Tunisian members of the genus (Diplopoda, Julida, Julidae)
}

\author{
Nesrine Akkari ${ }^{1, \dagger}$, David Koon-Bong Cheung ${ }^{1, \ddagger}$, Henrik Enghoffl, ${ }^{1,}$ Pavel Stoev ${ }^{2,3, I}$ \\ I Natural History Museum of Denmark, University of Copenhagen, Universitetsparken 15, DK-2100 Køben- \\ havn Ø, Denmark 2 National Museum of Natural History, Bulgarian Academy of Sciences 3 Pensoft Publi- \\ shers, 12, Prof. Georgi Zlatarski St., 1700 Sofia, Bulgaria \\ † http://zoobank.org/8DF67798-8E47-4286-8A79-C3A66B46A10F \\ † http://zoobank.org/B47D6016-19EC-48F3-BF55-F758478E1B8C \\ § http://zoobank.org/9B9D901F-D6C8-4BCA-B11B-CF6EE85B16DC \\ | http://zoobank.org/333ECF33-329C-4BC2-BD6A-8D98F6E340D4 \\ Corresponding author: Nesrine Akkari (nakkari@snm.ku.dk; nes.akkari@gmail.com)
}

Academic editor: Robert Mesibov | Received 10 June 2013 | Accepted 31 July 2013 | Published 3 September 2013

http://zoobank.org/EAEE5ABC-5C3E-42EB-B614-7653C8B9B2DD

Citation: Akkari N, Cheung DK-B, Enghoff H, Stoev P (2013) Revolving SEM images visualising 3D taxonomic characters: application to six species of the millipede genus Ommatoiulus Latzel, 1884, with description of seven new species and an interactive key to the Tunisian members of the genus (Diplopoda, Julida, Julidae). ZooKeys 328: 5-45. doi: $10.3897 /$ zookeys.328.5763

\begin{abstract}
A novel illustration technique based on scanning electron microscopy is used for the first time to enhance taxonomic descriptions. The male genitalia (gonopods) of six species of millipedes are used for construction of interactive imaging models. Each model is a compilation of a number of SEM images taken consecutively while rotating the SEM stage $360^{\circ}$, which allows the structure in question to be seen from all angles of view in one plane. Seven new species of the genus Ommatoiulus collected in Tunisia are described: O. chambiensis, O. crassinigripes, O. kefi, O. khroumiriensis, O. xerophilus, O. xenos, and O. zaghouani spp. n. Size differences between syntopic adult males of $O$. chambiensis and O. xerophilus spp. n. from Châambi Mountain are illustrated using scatter diagrams. A similar diagram is used to illustrate size differences in O. crassinigripes, O. khroumiriensis spp. n. and O. punicus (Brölemann, 1894). In addition to morphological differences, the latter three species display allopatric distribution and different habitat
\end{abstract}

Copyright Nesrine Akkari et al. This is an open access article distributed under the terms of the Creative Commons Attribution License 3.0 (CC-BY), which permits unrestricted use, distribution, and reproduction in any medium, provided the original author and source are credited. 
preferences. A dichotomous interactive key with a high visual impact and an intuitive user interface is presented to serve identification of the 12 Ommatoiulus species so far known from Tunisia. Updates on the North African Ommatoiulus fauna in general are presented.

\section{Keywords}

Taxonomy, millipedes, Diplopoda, Ommatoiulus, new species, North Africa, interactive SEM images, interactive key

\section{Introduction}

Description of new species is just one among many tasks of taxonomists (Enghoff and Seberg 2006), but this task is becoming increasingly urgent due to the continuing global decline of biodiversity. However, descriptive taxonomy has a big problem with keeping up to speed. Thus, it has recently been estimated that it takes on average 21 years for a species from being discovered and collected to be formally named and described (Fontaine et al. 2012). The 'shelf life' was, for example, ca. 150 years for Ommatoiulus schubarti Akkari \& Enghoff, 2012, a species collected for the first and hitherto only time in 1863 (Akkari and Enghoff 2012).

Enhancing and modernizing taxonomy constitutes one of the main challenges of this century, and several pilot projects and initiatives have been taken in this respect (see La Salle et al. 2009, Deans et al. 2012, Erwin et al. 2012). Nevertheless, there is still scope for improvement of efficiency. Costello et al. (2013) listed 14 "Actions to increase the species description rates and taxonomic efficiency", including "Use of digital imaging and molecular technologies to accelerate the description of species" and "Increased availability and access to museum and herbarium specimens, particularly type specimens through exchanges, loans, and on-line imaging .....".

It is natural that the word "imaging" appears in two of Costello et al.'s 14 action points, because nowhere is the saying "a picture is worth a thousand words" more true than in taxonomic descriptions. Early taxonomic works often included excellent drawings. In the course of time, drawings have been supplemented with photographs, microphotographs, SEM micrographs, multi-focus images, and (most recently) images produced by confocal laser scanning microscopy (cLSM), optical projection tomography (OPT), magnetic resonance imaging (MRI) and micro-Computed Tomography scan (e.g., Heim and Nickel 2010, Błażejowski et al. 2011, Görög et al. 2012, Faulwetter et al. 2013). The latter authors in particular have made a significant contribution in this field, suggesting that virtual specimens prepared by means of micro-CT scan may replace type specimens for some purposes.

To demonstrate a new technique for visualization of taxonomic characters described in detail in Cheung et al. (2013) we use six species of the millipede genus Ommatoiulus Latzel, 1884 from Tunisia. We describe 7 new Ommatoiulus species and offer an interactive and highly visual key to all 12 Ommatoiulus species from Tunisia for users with a suitable browser plug-in or Flash viewer.

This work is part of an ongoing project of revising the tribe Schizophyllini (Akkari and Enghoff 2011, 2012, Akkari 2013). 


\section{Taxonomic characters in millipedes and associated problems}

The male copulatory organs, or gonopods, are of prime importance for characterising millipede species and higher taxa. There are exceptions, where different species have identical or almost identical gonopods, e.g., several genera of Juliformia, such as Nepalmatoiulus Mauriès, 1983 (Enghoff 1987), Dolichoiulus Verhoeff, 1900 (Enghoff 1992), Pachyiulus Berlese, 1883 (Frederiksen et al. 2012), Anadenobolus Silvestri, 1897 (Bond and Sierwald 2002) and Thyropygus Pocock, 1894 (Pimvichai et al. 2011a, b), and of Nematophora, e.g., Sinocallipus Zhang, 1993 (Stoev and Enghoff 2011). By and large, however, the gonopods carry enough information to recognize species, and for more than 150 years authors have focused on describing and illustrating these structures in the most reliable way (Highton 2009).

As useful as gonopod illustrations are for taxonomic descriptions, they can sometimes be grossly misleading and result in misidentification and production of synonymic names, the Achilles' heel of descriptive taxonomy. There are several examples of this in the literature about millipedes, but most striking is perhaps the case presented by Hauser (2000) who demonstrated that amongst 11 subspecies and 100 varieties described for Craspedosoma alemannicum Verhoeff, 1910 (see Schubart 1963a), based on differences in the length of podosternite (posterior gonopods) processes, only $9 \%$ are valid while the rest can be discarded. The reason for this is that the 'heterodactyly' on which Verhoeff $(1915,1916,1917,1939)$ based his infraspecific Craspedosoma taxonomy and which was subsequently adopted by most authors studying the taxonomy and ecology of the genus, was simply due to observation error. When the podosternite of Craspedosoma is viewed from varying angles, the relative lengths of its processes change (see Hauser 2000, figs 1, 2, 3).

Useful taxonomic characters in Ommatoiulus are almost exclusively derived from the gonopods. Differences between species are often subtle, and the pronouncedly "3D" nature of the gonopods makes recognition of the differences difficult. In many older papers dealing with Ommatoiulus taxonomy, authors have dissected the different parts of the gonopods and have illustrated them separately which has led not only to "angle-of-view" problems, but also to difficulties of relating the various gonopod components spatially to each other. By applying the novel imaging technique we have overcome these problems.

\section{The study group: Ommatoiulus millipedes from Tunisia}

Ommatoiulus is the dominant genus of julid millipedes in North Africa and the Iberian Peninsula. A total of 70 species have been described so far, and many more remain to be recognised and named. For example, Akkari and Enghoff (2012) recorded $19 \mathrm{Om}$ matoiulus species in the southernmost Spanish region, Andalusia, 10 of which they described as new. These authors further provided a historical overview tracing the general inconclusive taxonomic situation and gave an updated definition of the genus based on 
morphological characters and a key to the 19 Andalusian species which they estimated to constitute at most $1 / 6$ of the total species richness for the genus. In spite of the wide distribution of a few species, e.g. O. sabulosus (Linnaeus, 1758) reaching $64^{\circ} \mathrm{N}$ in Fennoscandia, and $O$. moreleti (Lucas, 1860) with a near-cosmopolitan, synanthropic distribution, most Ommatoiulus species are confined to the Mediterranean region of North Africa and Iberia, and tend even to display small-scale endemism. For instance, of the 19 species recorded from Andalusia, only five were found in other areas (Akkari and Enghoff 2012).

North African species of the genus were examined in considerable detail by several authors, especially Brolemann (1921, 1924, 1925a, b) and Schubart (1952, 1960, 1963b). Recent studies have mostly targeted the Tunisian fauna, describing new species (Akkari and Voigtländer 2007, Akkari and Enghoff 2011) and in some cases detailing some aspects of developmental modalities (Akkari and Enghoff 2011). Akkari et al. (2009) presented detailed species accounts and new records from Tunisia in addition to a complete bibliographical review of the order Julida in North Africa, listing 24 Ommatoiulus species for the region.

Despite these contributions, the North African Ommatoiulus fauna is far from being thoroughly assessed, nor is its taxonomy close to being fully revised. Without doubt, numerous new species still await discovery, and several taxonomic questions still remain unsolved, such as the correct placement of the highly deviating species O. lapidarius (Lucas, 1846), type species of the subgenus Apareiulus Brölemann, 1897 (e.g., Attems 1952, Schubart 1963b). The same applies to the O. punicus species group established to facilitate understanding species affinities (Akkari and Voigtländer 2007) but which, in the light of recent revisionary work on the genus (Akkari and Enghoff 2012), might not reflect true relationships. To solve these questions an exhaustive revision of the genus in this area is needed.

\section{Material and methods}

Most specimens were hand collected during spring 2008 by N.A. and P.S. Supplementary material was obtained from museum collections. All studied specimens are preserved in 70\% alcohol. Measurements were made using a Leica Wild M10 microscope equipped with an ocular micrometre. Photographs were taken using Visionary Digital's BK Plus Lab with a Canon EOS 7D. For scanning electron microscopy, parts of the specimens were cleaned with ultrasound, transferred to $96 \%$ ethanol then to acetone, air-dried, mounted on adhesive electrical tape attached to aluminium stubs, coated with platinum/palladium and studied in a JEOL JSM- $6335 \mathrm{~F}$ scanning electron microscope. Photographs were processed with a Leica Application Suite program and final stacking made with Zerene Stacker 1.04. The rotatable images were constructed from 18 SEM images taken at 20 degrees intervals starting from the mesal view and continuing until all 360 degrees were captured by rotating the SEM stage. The images were processed using Adobe Lightroom 4.3 by adjusting the black, highlight and white levels to achieve a uni- 
form background and contrast. Each image was then cropped to ensure a smooth transition between each frame during rotation. The images were imported into Adobe Flash CS5, where each image was made into a single frame and the series combined to form a rotating animation. The animation controls (moving from one frame to the next) were mapped to the mouse cursor using Actionscript 3.0. The html version available online was compiled using Magic 360. The interactive key was developed in Adobe Flash CS5.5 using Actionscript 2.0 to handle screen transitions and image swapping. Plates were assembled using Adobe Indesign CS 5.5. Respective image libraries of the interactive rSEM have been deposited in MorphBank. More details on the method of creation of the interactive models can be found in Cheung et al. (2013). The number of body rings is given as recommended by Enghoff et al. (1993): Number of podous rings (PR) + number of apodous rings $(\mathrm{AR})+$ telson $(\mathrm{T})$. The developmental stadium of a number of individuals was taken as being represented by the number of vertical rows of ocelli (RO). The real stadium number in julid millipedes has been shown to equal the number of $\mathrm{RO}+1$ (Enghoff et al. 1993), e.g., a specimen with 9RO belongs to developmental stadium 10.

\section{Abbreviations}

AR apodous rings

H vertical midbody diameter (height)

L body length

MNHN Muséum National d'histoire Naturelle, Paris

MSNB Museo Civico di Storia Naturale 'Enrico Caffi', Bergamo, Italy

NMNHS National Museum of Natural History, Sofia

PR podous rings

RO vertical rows of ocelli

T telson

ZMUC Natural History Museum of Denmark (Zoological Museum), University of Copenhagen

\section{Results}

Order Julida Brandt, 1833

Family Julidae Leach, 1814

Tribe Schizophyllini Verhoeff, 1909

\section{Genus Ommatoiulus Latzel, 1884}

http://species-id.net/wiki/Ommatoiulus

Remarks. A general characterisation of Ommatoiulus was given by Akkari and Enghoff (2012). Delimitation of Ommatoiulus vis-à-vis related nominal genera such as Tachy- 
podoiulus Verhoeff, 1893 and Rossiulus Attems, 1926 is not very clear at present and will probably remain so until the ongoing comprehensive revision of Schizophyllini has been completed (see Akkari and Enghoff 2012).

Of the ca. 70 species of Ommatoiulus currently recognized, the following occur in Tunisia:

Ommatoiulus chambiensis Akkari \& Enghoff, sp. n.

Ommatoiulus crassinigripes Akkari \& Enghoff, sp. n.

Ommatoiulus fuscounilineatus (Lucas, 1846)

Ommatoiulus kefi Akkari \& Enghoff, sp. n.

Ommatoiulus khroumiriensis Akkari \& Enghoff, sp. n.

Ommatoiulus malleatus Akkari \& Voigtländer, 2007

Ommatoiulus punicus (Brölemann, 1894)

Ommatoiulus sempervirilis Akkari \& Enghoff, 2011

Ommatoiulus seurati (Brolemann, 1925)

Ommatoiulus xenos Akkari \& Enghoff, sp. n.

Ommatoiulus xerophilus Akkari \& Enghoff, sp. n.

Ommatoiulus zaghouani Akkari \& Enghoff, sp. n.

\section{Ommatoiulus chambiensis Akkari \& Enghoff, sp. n.}

http://zoobank.org/C6950942-CCF3-43CA-96FF-75F9166168ED

http://species-id.net/wiki/Ommatoiulus_chambiensis

Figs 1-6

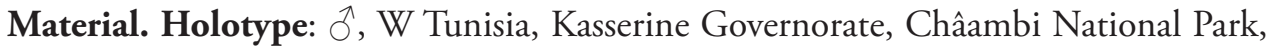
surroundings of the park's guest house, $35^{\circ} 10.139^{\prime} \mathrm{N}, 8^{\circ} 40.486^{\prime} \mathrm{E}$, alt. $950-1000 \mathrm{~m}$, scarce trees, Pinus halepensis, under stones, 7.3.2008, P. Stoev \& N. Akkari leg. (ZMUC). Paratypes: 17 กิ $\widehat{\jmath}, 31$ 우, 1 immature, same data as holotype (ZMUC);

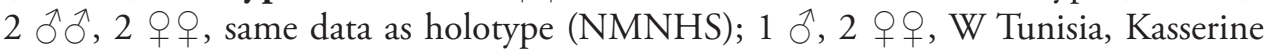
Governorate, Châambi National Park, 35¹1. 901'N, 8³9.505'E, alt. $1291 \mathrm{~m}$, Quercus ilex, Pinus halepensis, slope, under stones and in leaf litter, 9.3.2008, P. Stoev \& N. Akkari leg. (ZMUC).

Diagnosis. Most similar to $O$. xerophilus sp. n., but easily distinguished by the shape of promerite and the presence of a distal notch and a small pointed process on solenomerite.

Etymology. Named after the type locality. Châambi Mountain is the highest mountain range in Tunisia, reaching $1550 \mathrm{~m}$ at peak Châambi.

Description. Males: L: $17-23 \mathrm{~mm}, \mathrm{H}: 1.6-2 \mathrm{~mm}, 46-49 \mathrm{PR}+1-2 \mathrm{AR}+\mathrm{T}$; females: L: $18.5-32.2 \mathrm{~mm}, \mathrm{H}: 2.4-3.6 \mathrm{~mm}, 44-50 \mathrm{PR}+1-2 \mathrm{AR}+\mathrm{T}$. General colour brownish with a black sputter, dorsally darker, with a black mid-dorsal line. Head 
dark brown to black with yellow spots in the occipital area, uniformly black frontally, with yellow spots at antennal level and labrum, the latter yellow and brighter; antennae dark brown. Prozonites covered with yellowish-brown spots on a blackish background, also laterally, interrupted by big black spots at ozopore level, dorsally black with a narrow transverse row of yellow spots anteriorly; metazonites glossy pale to whitish; legs light brown to yellowish. Telson: anal valves black, with a yellow sputter, preanal ring black, somewhat paler on the caudal projection; subanal scale light brown. Prozonites with fine oblique striae; metazonites with regular striation, laterally narrower; suture complete, strongly curving at ozopore level; ozopores small, rounded, situated on metazonites, at about their diameter from the suture. Anal valves with numerous submarginal and marginal setae, ca. 2 setae on the surface; subanal scale rounded and setose; preanal ring protruding in a caudal projection with ca. $3+3$ setae on the tip and a small hyaline process.

Male sexual characters. Mandibular stipites expanded in well-rounded posteriorventral lobes, first pair of legs hook-shaped, remaining legs with postfemoral and tibial pads.

Gonopods. Promerite (P) bent anteriad (Figs 1, 2), proximally subrectangular, gradually narrowing in its distal third (Figs 1,2); lateral margin with a moderately deep rounded incision (i). In a posterior view showing a distal process expanded in a subtriangular shape, bearing an apical blunt process (ap) and a lateral broad process pointing basad (lp); mesal ridge (M) apically broadened and delimiting a serrated lateral lamellar process; distal process laterally bearing a strong serrated ridge (se) marking a thickness on the posterior surface; telopodite $(\mathbf{T})$ remnant ovoid located in the middle of the proximal part.

Posterior gonopod (Figs 3-6): Mesomerite (Ms) longer than the other processes of the gonopods, distally curved mesad and narrowing into an apical process folded and tapering toward the apex. Solenomerite (S) broad, slightly narrowing at midlength, proximally with several strong spikes (sp) on the posterior margin; anterior margin with a big, serrated process (pr) pointing distad, separated from the apical part by a rounded notch (n); apical part with an anterior marginally furrowed lamella (Figs 1, 4-6), and a setose wrinkled protruding lamella (wl) covering a protruding slender process (ds) (Figs 1,3-6) housing the distal part and the opening of the seminal groove $(\mathbf{g})$, the latter running from the fovea $(\mathbf{F})$ at the base of the solenomerite up to process ds. Paracoxite $(\mathbf{P x})$ broad and curved, emerging from a well-rounded coxite $(\mathbf{C o})$, distal third broad then gradually narrowing in a rounded apex pointing mesad (Figs 3-6).

Distribution. Known only from the type locality, Châambi Mountain, Arid Bioclimatic zone, central Tunisia.

Habitat. Mixed forest with Quercus ilex and Pinus halepensis, under stones and in leaf litter. 

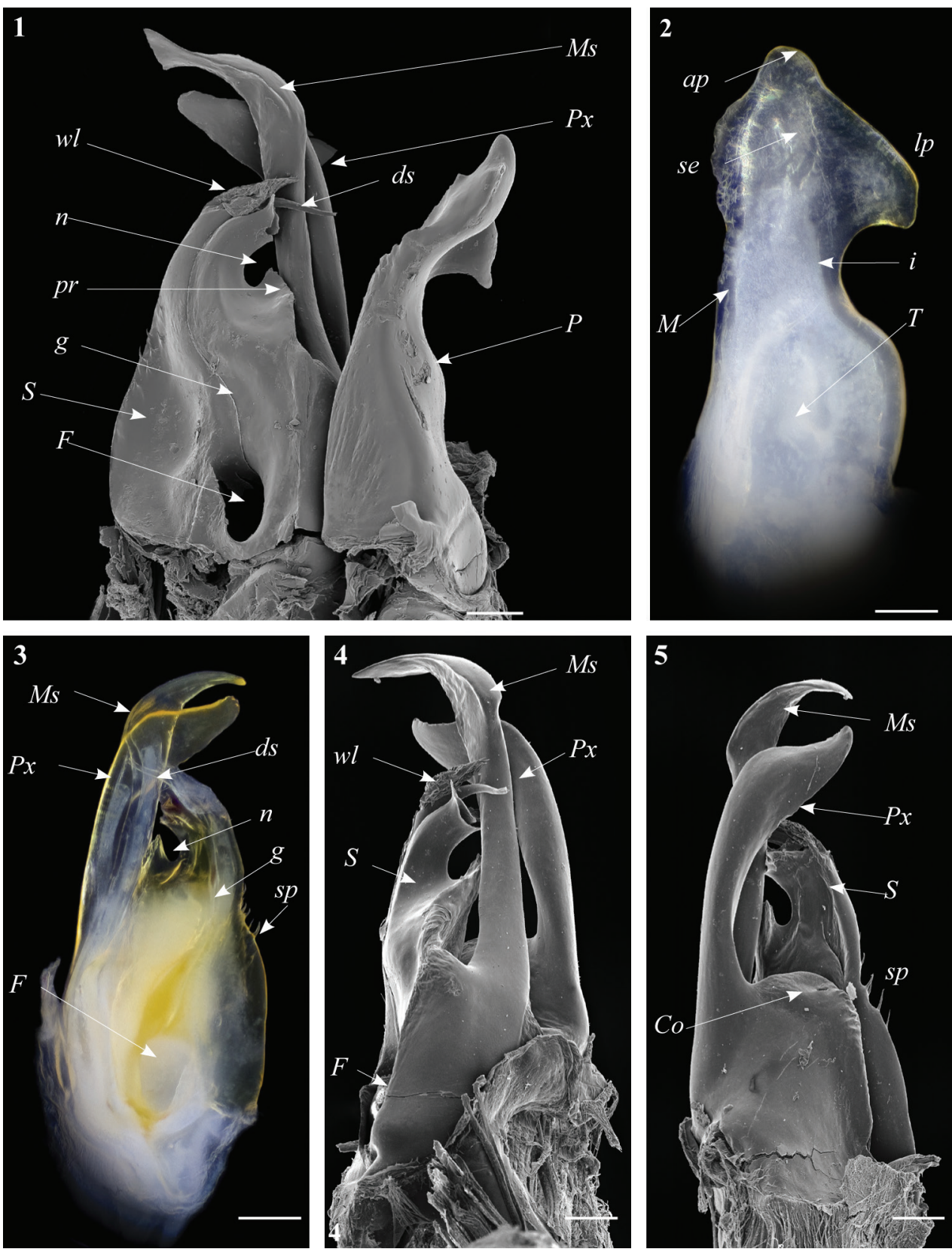

Figures I-5. Ommatoiulus chambiensis sp. n. paratype, gonopod structures. I Right gonopod, mesal view $\mathbf{2}$ Left promerite, posterior view $\mathbf{3}$ Left posterior gonopod, mesal view $\mathbf{4}$ Right posterior gonopod, anterior view $\mathbf{5}$ Right posterior gonopod, posterior view. Abbreviations: ap apical process, ds distal process of the solenomerite, $\mathbf{F}$ fovea, $\mathbf{g}$ seminal groove, $\mathbf{i}$ incision on lateral margin of the promerite, $\mathbf{l} \mathbf{p}$ lateral apical process of promerite, $\mathbf{M}$ mesal ridge, $\mathbf{M s}$ mesomerite, $\mathbf{P}$ promerite, $\mathbf{p r}$ triangular process of the solenomerite, $\mathbf{P x}$ paracoxite, $\mathbf{S}$ solenomerite, se serrations, $\mathbf{s p}$ spikes, $\mathbf{T}$ remnant of telopodite, $\mathbf{w l}$ wrinkled lamella. Scale bar: $0.1 \mathrm{~mm}$. 


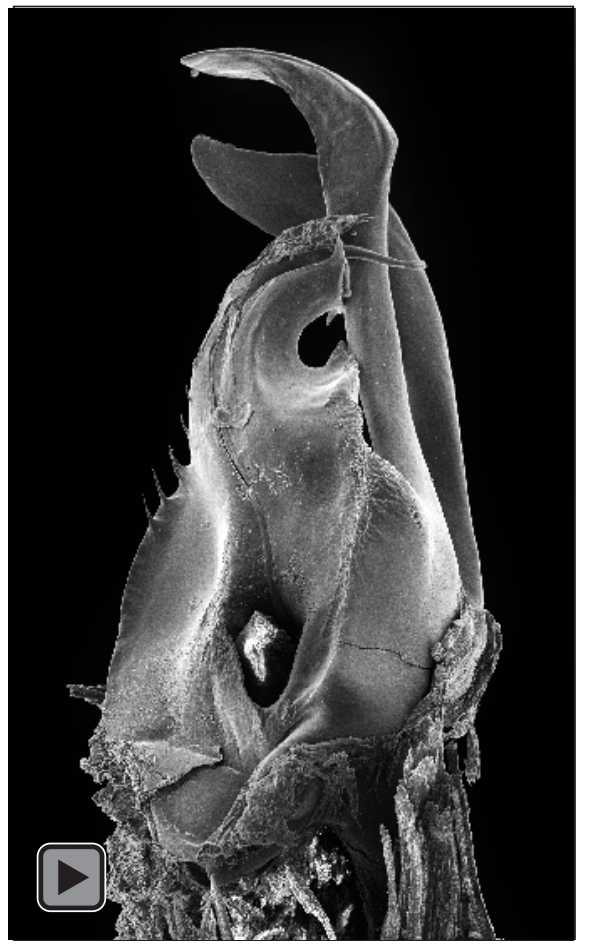

Figure 6. Ommatoiulus chambiensis sp. n. paratype, right posterior gonopod. Interactive rotating SEM image. [Morphbank \# 831160-831177, 831188]

\section{Ommatoiulus crassinigripes Akkari \& Enghoff, sp. n.}

http://zoobank.org/82B068D7-2ABD-4771-9899-2F2E2C51B9CA http://species-id.net/wiki/Ommatoiulus_crassinigripes

Figs 7-13

Schizophyllum punicum: Attems 1903: 144, figs 77-81.

Ommatoiulus punicus: Akkari et al. 2009, in part.

Material. Holotype: đ̊, W Tunisia, Kasserine Governorate, Châambi National Park, Châambi peak and its surroundings, $35^{\circ} 12.285^{\prime} \mathrm{N}, 8^{\circ} 40.653^{\prime} \mathrm{E}$, alt. 1500-1540m, Quercus ilex, Pinus halepensis, under stones and leaf litter, 9.3.2008, P. Stoev \& N. Akkari leg. (ZMUC). Paratypes: $4 \hat{\jmath} \widehat{\sigma}, 2$ 우, same data as holotype (ZMUC); $1 \hat{\sigma}$, 1 , same data as holotype (NMNHS); 1 o, 3 우, 3 juveniles, CW Tunisia, El Kef, 21.4.1983, Bianchi \& Moretti leg. (MSNB); 3 ㅊํ, 11 우, 1 intercalary male, 30 juveniles, CW Tunisia, Makthar, 9.3.1986, Bianchi \& Moretti leg. (MSNB); 6 우, 2 subadults, CW Tunisia, $12 \mathrm{~km} S$ Thala, 10.3.1986, Bianchi \& Moretti leg. (MSNB); 2 ऽึ่, 12 우, 4 juveniles, C Tunisia, Kairouan Governorate, El Manara, on the road

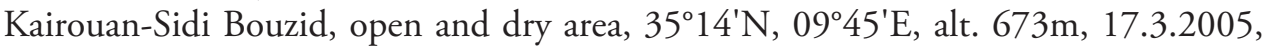
N. Akkari leg. (ZMUC). 
Diagnosis. Gonopods resembling those of $O$. punicus and O. khroumiriensis sp. n., but differing by the shape of promerite, a much broader and strongly serrated paracoxite, a broader mesomerite bearing subapical serrations on the mesal margin, and the apical processes on solenomerite.

Etymology. An adjunction of Latin words referring to the body size and leg colour, crassus meaning fat and nigripes, black leg.

Description. Males: L: 24.8-30 mm, H: 2.7-3.6 mm, 45-53 PR+1-2 AR+T. Females: 30-34 mm, H: 3.4-3.9 mm, 45-47 PR+1-2 AR+T. General colour grey, with alternating pale grey and golden brown, darker laterally, with a thin black mid-dorsal line. Head grey, with black sputter frontally, labral zone reddish-brown, brighter at the margin, antennae dark brown. Prozonites pale grey, with big black spots at the level of ozopores and below, a dense black sputter; metazonites whitish anteriorly and golden brown posteriorly, legs black. Telson: anal valves dark grey, bordered with black, preanal ring golden brown, darker on the tip of the caudal projection; subanal scale yellowish. Prozonites with scattered oblique striae; metazonites with regular striation becoming dense laterally; ozopores small and rounded, appearing as brown rounded spots located on metazonites, situated at about their diameter from the suture; the latter complete, only slightly curving at the level of ozopores. Anal valves mostly glabrous at the surface but bearing several submarginal and shorter marginal setae; subanal scale triangular, blunt and setose; preanal ring protruding in a caudal projection, with ca. $2+2$ setae and a small hyaline process on the tip.

Male sexual characters. Mandibular stipites expanded in well-rounded posterior-ventral lobes, first pair of legs hook-shaped, remaining legs with postfemoral and tibial pads.

Gonopods. Promerite (Fig. 7) broad, proximally almost rectilinear, bent 90 degrees at notch level; strongly narrowing in its distal third with a deep incision (i) on the lateral margin, latter almost rectilinear; mesal ridge $(\mathbf{M})$ broad distally, protruding in a blunt process (mp) (Fig. 7); posterior surface irregular on the mesal side, bearing a number of strong setae aligned in front of the notch; distal process (ap) laterally broadened and rounded, showing a small mesal serrated process (ap1); remnant of telopodite $(\mathbf{T})$ as a small bump located proximally.

Posterior gonopod (Figs 8-13). Mesomerite (Ms) long, sinuous, distal part asymmetrically enlarged mesolaterally, and showing in lateral view strong serrations at different levels on both margins (Figs 8, 9, 13), gradually narrowed apically in a hookshaped process (ho) curved and tapering toward the apex (Figs 11, 12, 13). Solenomerite $(\mathbf{S})$ broadest at the base, narrowing at mid-length and bearing a number of strong setae near the posterior margin (Figs 10, 12, 13); in mesal view showing at mid-length a triangular process (pr) pointing distad (Figs 10, 13), latter separated from the apical part by a deep rounded notch (n); apically bearing a long curved process (ds) pointing mesad, housing the distal part and the opening of the seminal groove $(\mathbf{g})$ and emerging between a posterior and an anterior folded hyaline processes (hp1, hp2) (Figs 11-13). Seminal groove running from the fovea (F) at the base of the solenomerite up to process $\mathbf{d s}$ (Figs 10, 13). Paracoxite (Px) lamellar, broad and folded, emerging from a rounded coxite $(\mathbf{C o})$, distally broadened, apical margin almost 

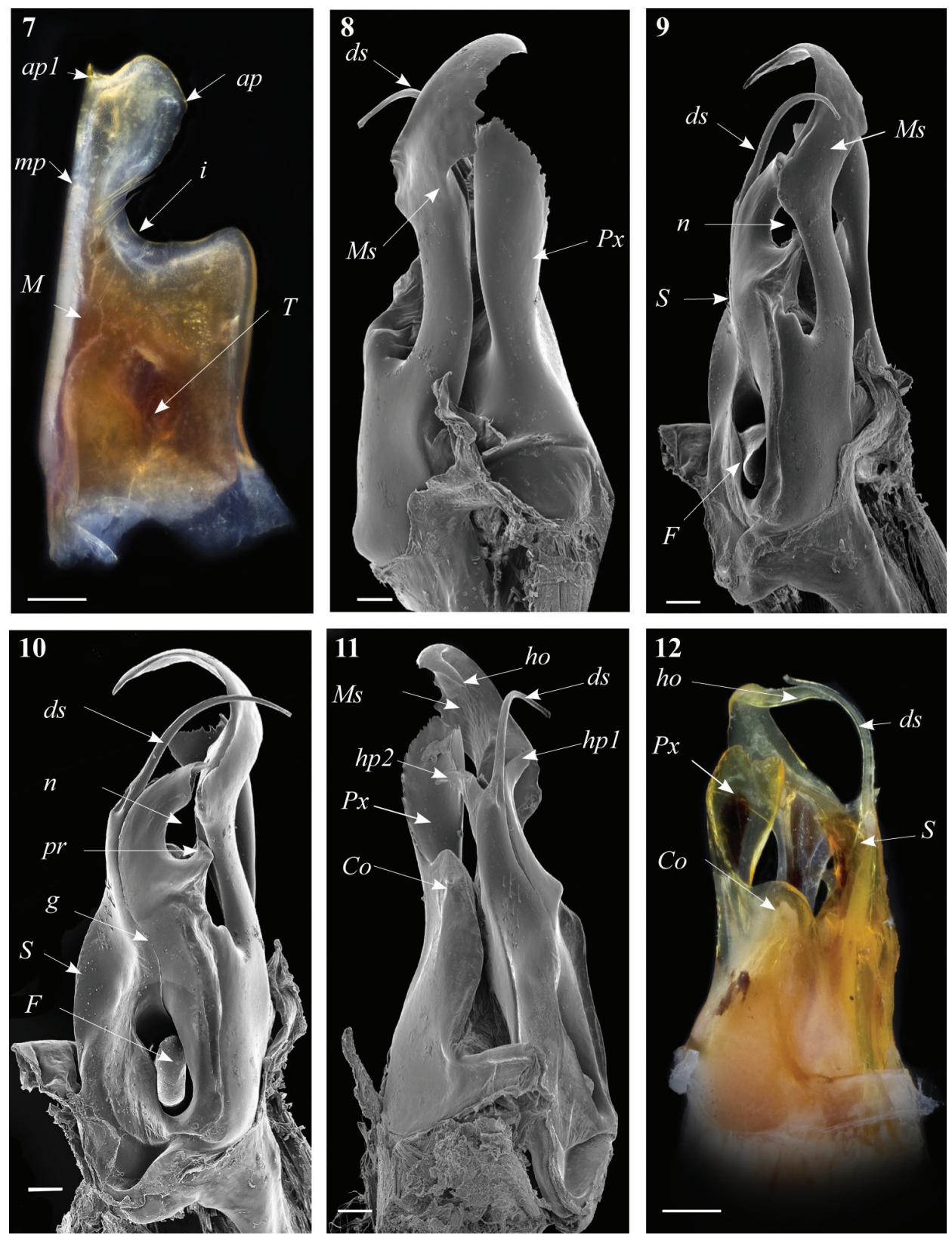

Figures 7-12. Ommatoiulus crassinigripes sp. n. paratype, gonopod structures. 7 Left promerite, posterior view 8 Right posterior gonopod, lateral view 9 Right posterior gonopod, anterior view 10 Right posterior gonopod, mesal view II Right posterior gonopod, posterior view I2 Right posterior gonopod latero-posterior view. Abbreviations: ap distal process of the promerite, ap1 apical mesal process, Co coxite, $\mathbf{d s}$ distal process of the solenomerite, $\mathbf{F}$ fovea, $\mathbf{g}$ seminal groove, ho hook-shaped process, hp1, hp1 distal processes of the solenomerite, $\mathbf{i}$ lateral margin incision of the promerite, $\mathbf{M}$ mesal ridge, $\mathbf{M s}$ mesomerite, $\mathbf{m p}$ distal blunt process of the mesal ridge, $\mathbf{n}$ notch of the solenomerite, $\mathbf{p r}$ triangular process of the solenomerite, Px paracoxite, $\mathbf{S}$ solenomerite, $\mathbf{T}$ remnant of telepodite. Scale bar: $0.1 \mathrm{~mm}$ 


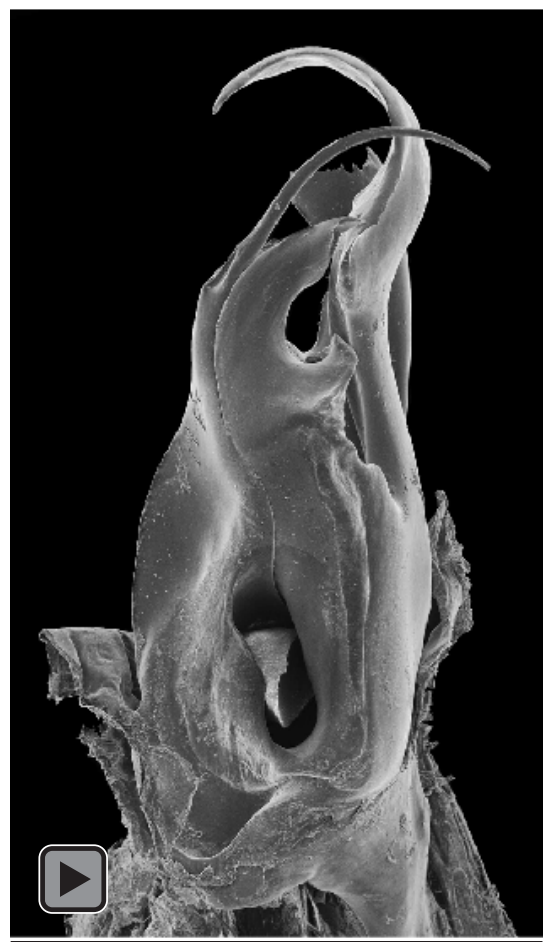

Figure 13. Ommatoiulus crassinigripes sp. n. paratype, right posterior gonopod. Interactive rotating SEM image. [Morphbank \# 831189-831207]

horizontal, and together with the posterior margin showing many strong, short serrations (Figs 8, 11-13).

Distribution. Semi-arid and Arid bioclimatic zones in west central Tunisia, recorded from the governorates Kasserine, El Kef, Thala and Kairouan.

Habitat. Dry and open habitats, to $1500 \mathrm{~m}$ in Châambi Mountain.

Ommatoiulus kefi Akkari \& Enghoff, sp. n. http://zoobank.org/93E41C97-AA12-45D5-BD86-F2B0ACF02465 http://species-id.net/wiki/Ommatoiulus_kefi Figs $14-19$

Material. Holotype: đ̂, W Tunisia, El Kef Governorate, 13 km S El Kef, 22.iv.1981, Bianchi \& Moretti leg. (MSNB).

Diagnosis. Differing from all congeners by having a tri-lobate distal part of promerite and a bifurcated apical part of mesomerite, the latter divided in two short oppositely directed processes.

Etymology. Named after El Kef city, the type locality of the species. 

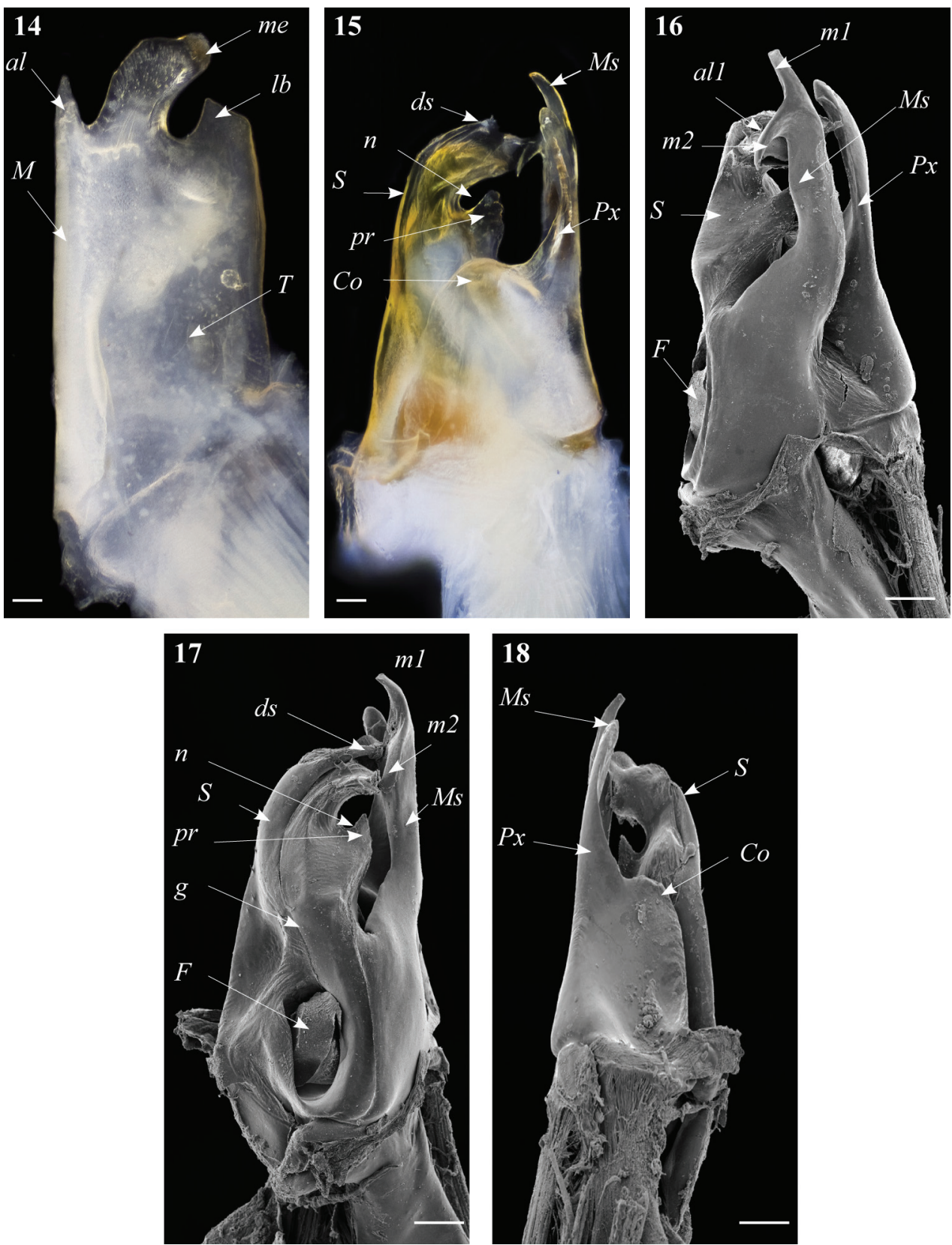

Figures I4-18. Ommatoiulus kefisp. n. holotype, gonopod structures. I 4 Left promerite, posterior view 15 Left posterior gonopod, posterior view 16 Right posterior gonopod, anterior view 17 Right posterior gonopod, mesal view $\mathbf{8}$ Right posterior gonopod, mesal view. Abbreviations: al apical lobe of the promerite, al1 apical folded lamella of the solenomerite, Co coxite, $\mathbf{d} \boldsymbol{s}$ distal process of the solenomerite, $\mathbf{F}$ fovea, $\mathbf{g}$ seminal groove, $\mathbf{l b}$ lateral lobe, $\mathbf{m 1} \mathbf{m} \mathbf{2}$ apical processes of the mesomerite, $\mathbf{M}$ mesal ridge, me median lobe, $\mathbf{M s}$ mesomerite, $\mathbf{n}$ notch of the solenomerite, $\mathbf{p r}$ triangular process of the solenomerite, Px paracoxite, $\mathbf{S}$ solenomerite, $\mathbf{T}$ telopodite. Scale bar: $0.1 \mathrm{~mm}$ 


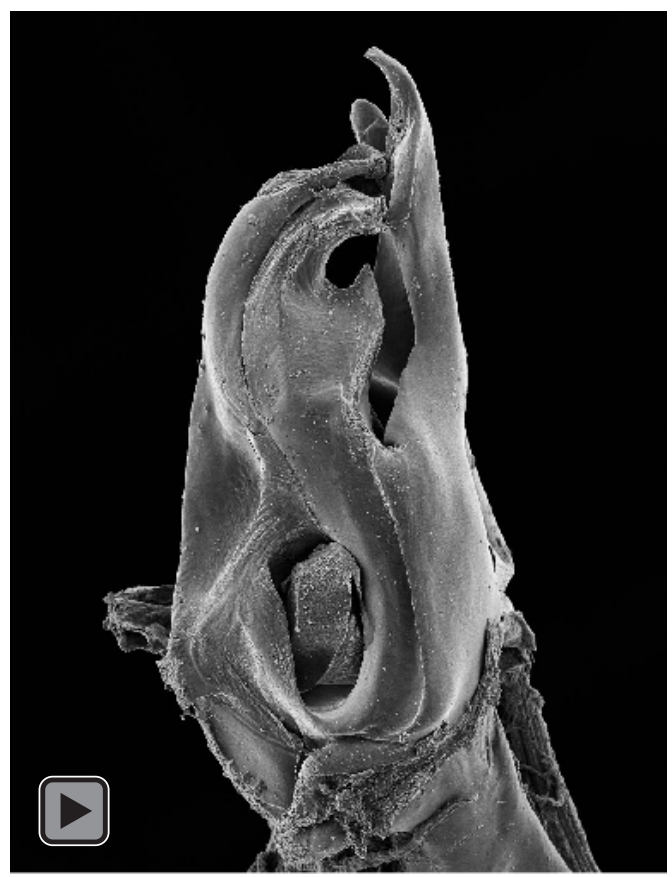

Figure 19. Ommatoiulus kefi sp. n. holotype, right posterior gonopod. Interactive SEM image. [Morphbank \# 831208-831227]

Description. Male: L: 26 mm, H: 2.7 mm, 53 PR+1 AR+T. General colour alternating whitish and blackish with a thin black mid-dorsal line. Head brown, lighter on the frontal part, with yellowish spots at antennal level, labral zone yellowish, becoming brighter at the margin, antennae brownish. Prozonites pale grey, dorsally scarcely sputtered with black; metazonites anteriorly dark, with a blackish background and a line of light brown spots below ozopores; legs whitish. Telson: anal valves and preanal ring blackish, paler towards caudal projection, subanal scale yellowish. Prozonites with scattered oblique striae; metazonites with regular striation becoming dense laterally; suture complete and rectilinear; ozopores small, rounded and located in metazonites, well apart from the suture. Anal valves with numerous submarginal and marginal setae and ca. 1-2 setae on the surface; subanal scale triangular, blunt and setose; preanal ring protruding in a caudal projection, with ca. $3+3$ setae and a small hyaline process on the tip.

Male sexual characters. Mandibular stipites expanded in rounded posterior-ventral lobes, first pair of legs hook-shaped, remaining legs with postfemoral and tibial pads.

Gonopods. Promerite (Fig. 14) in posterior view subrectangular, mesal ridge (M) fairly broad, distally narrowing and protruding into a pointed apical lobe (al); apical margin protruding in a curved median lobe (me) pointing laterad and a shorter broad lateral lobe (lb); the three apical lobes separated by two rounded incisions; lateral margin almost rectilinear. Remnant of telopodite $(\mathbf{T})$ ovoid, located at mid-length of promerite.

Posterior gonopod (Figs 15-19): Mesomerite (Ms) broadest at the base, distally protruding in a uniformly broad process, apically splitting into two short and curved 
processes, pointing in opposite directions (m1, m2) (Fig 16, 17, 19); solenomerite (S) broad at the base, slightly narrowing at mid-length and showing a triangular process (pr) separated from the rest of the processes by a rounded (n) (Figs 17, 19), apical part of the solenomerite complex with a broad lamella (al1) extended latero-mesad, downturned and marginally furrowed (Fig. 16). Seminal groove (g) running from the fovea $(\mathbf{F})$ at the base of solenomerite up to a slender and short conical process (ds) emerging on top of the median part of the apical lamella and pointing anteriad (Figs 15, 17). Paracoxite (Px) stout, with smooth margins, emerging from a broad rounded coxite (Co) (Figs 18, 19).

Distribution. Semi-arid bioclimatic zone in western Tunisia; hitherto known only from the type locality near El Kef city.

Comments. We have examined three females (MSNB) collected from the same locality but could not assign them with certainty to $O$. kefi as they show a different colour pattern.

\section{Ommatoiulus khroumiriensis Akkari \& Enghoff, sp. $\mathrm{n}$.}

http://zoobank.org/05BAED95-725C-4395-92C3-6BF22A01CE18

http://species-id.net/wiki/Ommatoiulus_khroumiriensis

Figs $20-26$

Archiulus punicus: Attems (1926): 191, figs 240, 241.

Ommatoiulus punicus: Akkari et al. 2009, in part.

Ommatoiulus cf. punicus: Enghoff et al. 2011: 610.

Material. Holotype: $\widehat{O}$, NW Tunisia, Jendouba Governorate, Aïn Draham, Col des Ruines, 1.11.2009, N. Akkari leg. (ZMUC). Paratypes: $2 \widehat{\partial} \delta^{2}, 5$ 우, NW Tunisia, Jendouba Governorate, Aïn Draham, Col des Ruines, 1.11.2009, N. Akkari leg. (ZMUC); 2 ㅅํ, 6 우, NW Tunisia, Jendouba Governorate, $7 \mathrm{~km}$ south Aïn Draham, les chênes, 22.3.1986, ZMUC expedition; 1 Ô, 1 q, 4 immatures, 5-18.3.1988, NW Tunisia, Jendouba Governorate, Aïn Draham area, ZMUC expedition; 1 Oे, 1 , 1 intercalary male, NW Tunisia, Jendouba Governorate, Aïn Draham, 19.11.2003, forest with Quercus suber and Quercus faginea, under stones, N. Akkari leg. (NMNHS);

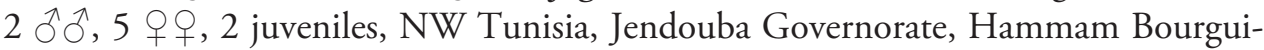
ba, $36^{\circ} 45^{\prime} \mathrm{N}, 08^{\circ} 35^{\prime} \mathrm{E}$, alt. $158 \mathrm{~m}$, mixed forest with Pinus pinaster and Quercus suber, under stones, 31.10.2009, N. Akkari leg. (ZMUC); 3 त $^{\lambda}$, NW Tunisia, Jendouba Governorate, Aïn Draham, 36 $47^{\prime} \mathrm{N}, 8^{\circ} 41^{\prime} \mathrm{E}$, alt. $511 \mathrm{~m}, 3.10 .2005$, N. Akkari leg. (ZMUC); 1 స, 2 우, NW Tunisia, Jendouba Governorate, Aïn Draham, 36 $47^{\circ} \mathrm{N}$, $8^{\circ} 41^{\prime} \mathrm{E}, 760 \mathrm{~m}$, Quercus suber-Erica forest, 11.3.2009, N. Akkari \& H. Enghoff leg.

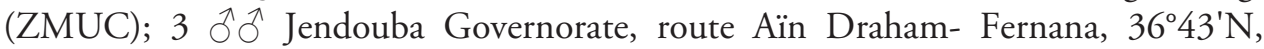
$8^{\circ} 40^{\prime} \mathrm{E}$, Quercus suber-Erica forest, 9.3.2009, N. Akkari \& H. Enghoff leg. (ZMUC); 1 ㄱ, 2 우우, Jendouba Governorate, route Aïn Draham- Béni M'tir, 36² $43^{\prime} \mathrm{N}, 8^{\circ} 42^{\prime} \mathrm{E}$, Quercus suber-Erica forest, 10.3.2009, N. Akkari \& H. Enghoff leg. (ZMUC).

Diagnosis. Similar to $O$. punicus and $O$. crassinigripes sp. n. but readily distinguished by the shape of promerite having a deeper notch extended basad, much slen- 
derer processes of posterior gonopods, and a more sinuous mesomerite devoid of conspicuous serrations.

Etymology. The species name refers to the natural region of Khroumirie, NW Tunisia, to which the species seems confined.

Description. Males: L: 26-27 mm, H: 2-2.8 mm, 43-48 PR+1-2 AR+T, females: L: $30-37 \mathrm{~mm}, \mathrm{H}$ : 4-4.3, 44-48 PR+1 AR+T. General colour dark grey, alternating with brown-yellow laterally, and with a thin black mid-dorsal line. Head dark reddishbrown; occipital area blackish, with brown-reddish- spots; frontal part uniformly black, labral zone brown-reddish- to yellowish at margin, antennae brownish. Prozonites uniformly grey, with a pale narrow stripe anteriorly; metazonites darker, brown-greyish, densely sputtered with black, colour gradually vanishing on the sides, below ozopore level yellow-brownish; legs light brown. Telson: anal valves black, preanal ring blackish, caudal projection brown-reddish, subanal scale light brown to yellowish.

Prozonites with scattered oblique striae; metazonites densely striated; suture complete, curving at ozopore level; ozopores small, rounded and located on metazonites, situated at about their diameter from the suture. Anal valves with 4-5 setae on the surface, a submarginal row of 12-13 setae and numerous short marginal ones; subanal scale triangular and setose; preanal ring protruding in a caudal projection with ca. $3+3$ setae and a small hyaline process on the tip.

Male sexual characters. Mandibular stipites expanded in rounded posterior-ventral lobes, first pair of legs hook-shaped, remaining legs with postfemoral and tibial pads.

Gonopods. Promerite (Fig. 20) strongly narrowed distally with a deep lateral incision (i) extending meso-basad, distal process (ap) broad, subtriangular, with two pointed edges, the tip of apical process with a small pointed lobe (ap2); mesal ridge (M) distally protruding in a blunt small cylindrical process ( $\mathbf{m p}$ ), posterior surface of promerite with a row of strong setae emerging at the level of the notch, in close proximity to the mesal ridge.

Posterior gonopod (Figs 21-26). Mesomerite (Ms) large, longer than the other processes, uniformly broad, sinuous; distal third constricted to less than half breadth and apically protruding into a slender curved process, latter tapering and pointing mesad (Figs 21, 23, 24, 26). Solenomerite ( $\mathbf{S}$ ) broadest at the base, narrowing at midlength, and bearing a number of strong setae near the posterior margin, distally with a broad, blunt triangular process (pr) separated from the apical part by a rounded notch (n), and with a long curved process (ds) protruding between two apical hyaline processes $(\mathbf{h p 3}$, hp4) and housing the apical part of seminal groove $(\mathbf{g})$, the latter $(\mathbf{g})$ running from the fovea $(\mathbf{F})$ located at the base of the solenomerite $(\mathbf{S})$ up to process $\mathbf{d s}$. Paracoxite $(\mathbf{P x})$ emerging from a depressed coxite $(\mathbf{C o})$; $\mathbf{P x}$ curved, half as broad as in $O$. crassinigripes, gradually narrowing distad; lateral and apical margins, with a saw-like strongly jagged margin (Figs 22-26).

Distribution. Humid bioclimatic zone in northwestern Tunisia; known from Aïn Draham, Fernana and Hammam Bourguiba in Khroumirie, Jendouba Governorate.

Habitat. Mixed forests dominated by Quercus faginea and Q. suber, or Pinus pinaster and Quercus suber. 

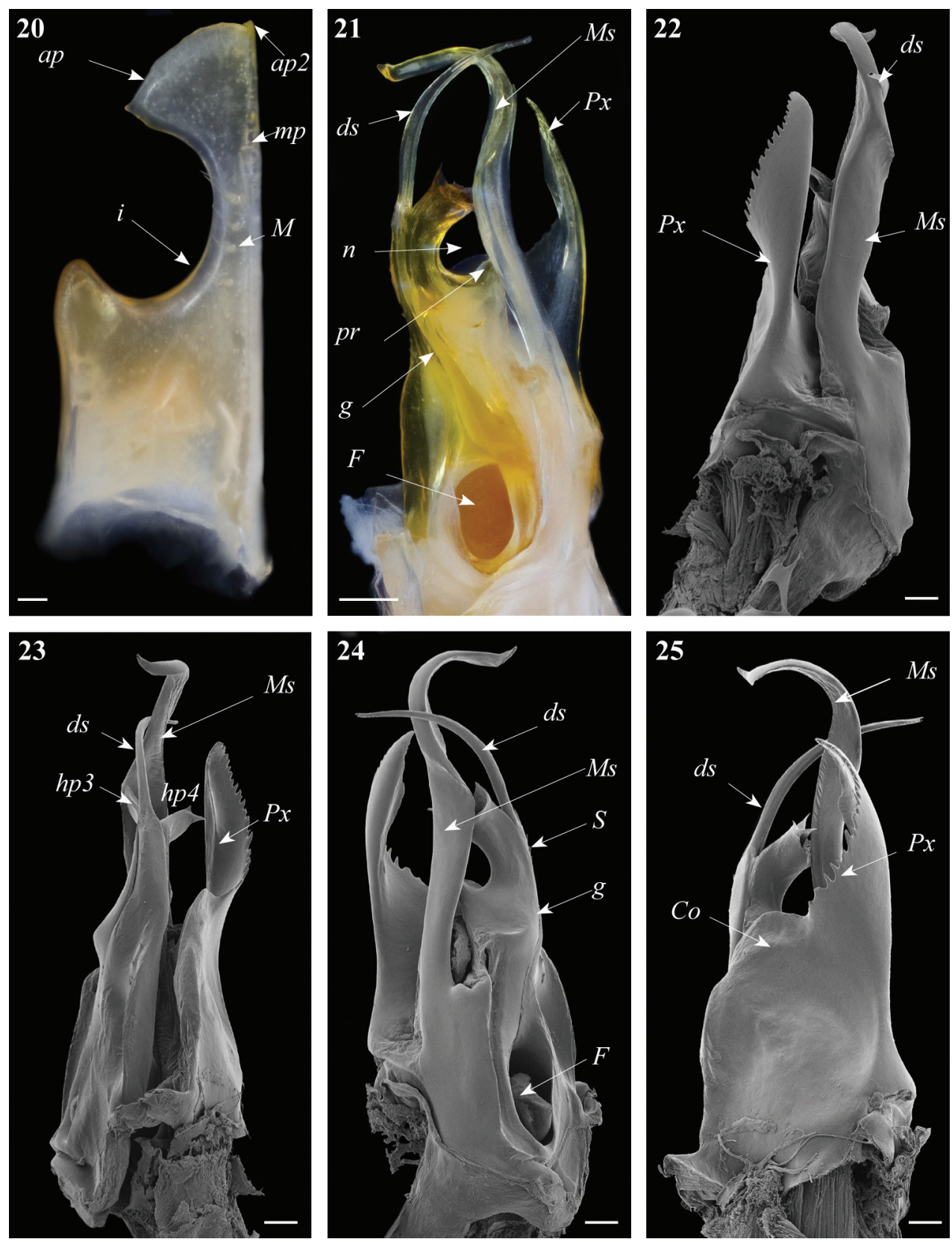

Figures 20-25. Ommatoiulus khroumiriensis sp. n. paratypes, gonopod structures. 20 Right promerite, posterior view 21 Right posterior gonopod, mesal view 22 Right posterior gonopod, lateral view $\mathbf{2 3}$ Right posterior gonopod, meso-posterior view $\mathbf{2 4}$ Right posterior gonopod, anterior-mesal view $\mathbf{2 5}$ Right posterior gonopod, anterior view. Abbreviations: ap distal process of the promerite, ap2 lobed process, Co coxite, ds distal process of the solenomerite, $\mathbf{F}$ fovea, $\mathbf{g}$ seminal groove, $\mathbf{h p 3}$, hp4 distal processes of the solenomerite, $\mathbf{i}$ lateral incision of the promerite, $\mathbf{m p}$ blunt mesal process, $\mathbf{M}$ mesal ridge, $\mathbf{M s}$ mesomerite, $\mathbf{n}$ notch of the solenomerite, pr triangular subapical process of the solenomerite, $\mathbf{P x}$ paracoxite, $\boldsymbol{S}$ solenomerite. Scale bar: $0.1 \mathrm{~mm}$. 


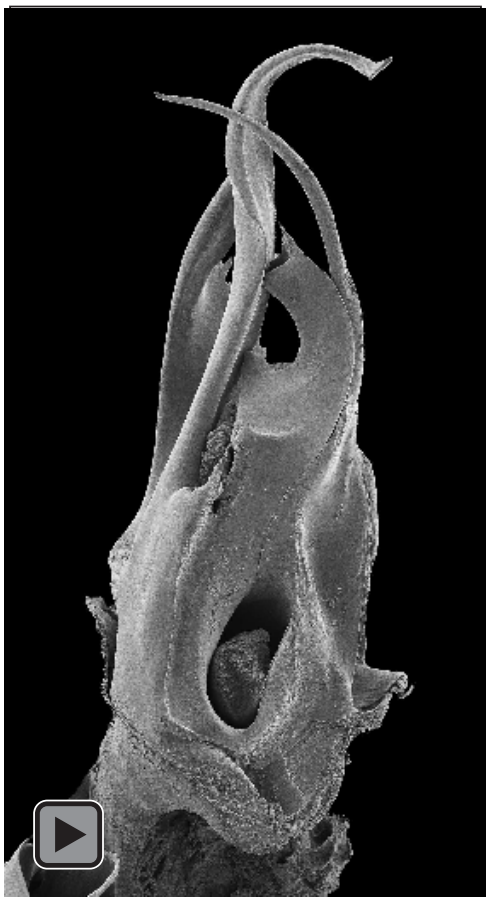

Figure 26. Ommatoiulus khroumiriensis sp. n. paratype, left posterior gonopod. Interactive SEM image. [Morphbank \# 831016-831034]

\section{Ommatoiulus xenos Akkari \& Enghoff, sp. n.} http://zoobank.org/09D98AF5-9AD3-41E0-8B54-624E31B72480 http://species-id.net/wiki/Ommatoiulus_xenos Figs $27-30$

Material. Holotype: $\widehat{\partial}$, Tunisia (“Tunis”), 1861, J.P. Coindé leg. (MNHN). Paratypes: 5 우, Tunisia (“Tunis"), 1861, J.P. Coindé leg. (MNHN).

Diagnosis. Resembling O. chambiensis and $O$. xerophilus spp. n. in size and general shape of gonopods, but distinguished by the shape of promerite, a much more slender mesomerite and shorter and stouter paracoxite.

Etymology. The species name is a Greek noun meaning 'stranger', emphasising the fact that this species, found surprisingly in the collection of the MNHN shortly before completion of the manuscript, had remained unknown and out of the sight of a number of myriapodologists for more than 150 years.

Description. Male: L: 20.5 mm, H: 1.85 mm, 47 PR+2 AR+T; females: L: 18.5-21 $\mathrm{mm}, \mathrm{H}: 2.26-2.46 \mathrm{~mm}, 42-48 \mathrm{PR}+2-3 \mathrm{AR}+\mathrm{T}$. General colour faded, generally greygreenish (very likely an artefact from the decomposition of the inserted label), somewhat lighter laterally. Head pale in the occipital and labral areas; antennae and legs darker. Prozonites with darker triangular spots laterally, latter situated along the ozopores line and forming two longitudinal dark bands, dorsally separated by a pale one; dorsum crossed 

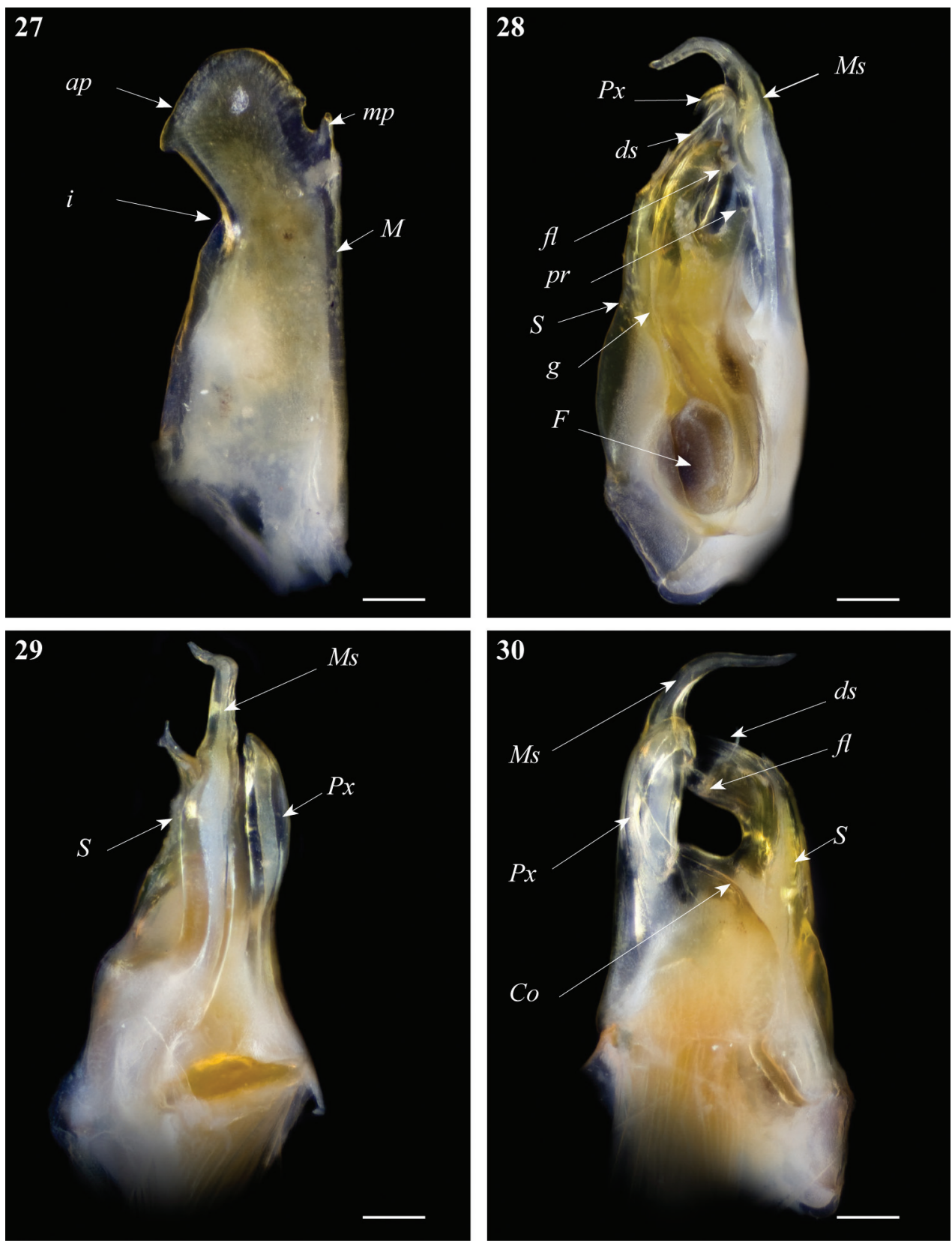

Figures 27-30. Ommatoiulus xenos sp. n. holotype, gonopod structures. 27 Right promerite, posterior view 28 Right posterior gonopod, mesal view 29 Right posterior gonopod, antero-lateral view 30 Right posterior gonopod, posterior view. Abbreviations: Co coxite, ds distal process of the solenomerite, $\mathbf{F}$ fovea, $\mathbf{f l}$ folded lamella, $\mathbf{g}$ seminal groove, $\mathbf{i}$ lateral incision of the promerite, $\mathbf{M}$ mesal ridge, $\mathbf{m p}$ distal process, $\mathbf{M} \boldsymbol{s}$ mesomerite, $\mathbf{p r}$ blunt process of the solenomerite, Px paracoxite, $\boldsymbol{S}$ solenomerite. Scale bar: $0.1 \mathrm{~mm}$. 
by dark triangular spots and showing a thin black mid-dorsal line; metazonites mostly pale and glossy. Telson: anal valves and preanal ring dark, subanal scale pale.

Prozonites with fine striae; metazonites with regular striae, denser on the sides, suture complete, curving at the level of ozopores; ozopores small, rounded, situated on metazonites situated at about their diameter from the suture. Anal valves setose; preanal ring with 3-4 setae on each lateral side, protruding in a short caudal projection with 1-4/5 setae and a small hyaline process on the tip. Subanal scale blunt to rounded and setose.

Male sexual characters. Mandibular stipites expanded in rounded posterior-ventral lobes, first pair of legs hook-shaped, remaining legs with postfemoral and tibial pads.

Gonopods. Promerite (Fig. 27) gradually narrowed distally, lateral margin with a shallow incision (i); apical process of promerite with a rounded margin pointing laterad; mesal ridge (M) narrow, distally protruding in a pointed apex (mp) separated from the apical process by a small apical incision; remnant of telopodite not very conspicuous.

Posterior gonopod (Figs 28-30): Mesomerite (Ms) uniformly broad proximally, strongly narrowed in its distal third and bent posteriad (Figs 28, 29); solenomerite (S) broad, with scattered setae on posterior margin, narrowing at mid-length, and bearing a large blunt process (pr); solenomerite apically with a broad folded lamella $(\mathbf{F l})$ and a small wrinkled lamella laying on the top of a slender and slightly protruding process (ds) housing the distal part of the seminal groove $(\mathbf{g})$; seminal groove running from the fovea $(\mathbf{F})$ and opening at the apex of process $\mathbf{d s}$ (Fig. 28). Paracoxite (Px) stout, distally curved mesad and narrowed into a slender apex pointing basad emerging from a broad and rounded coxite (Co) (Fig. 30).

Distribution. Exact locality unknown. The label mentions 'Tunis' which presumably refers to Tunisia in general.

Habitat. Unknown.

Remarks. The collector of this species, J.P. Coindé, who was a 'zoologist-traveler', made a collecting trip to Tunisia in 1861 during which he visited several localities throughout the country. Although we are certain that $O$. xenos sp. n., found by chance in an obscure jar among several unidentified myriapods from North Africa, labelled 'Brolemann unidentified', was collected in Tunisia, we couldn't determine with certainty the locality where this species was collected 152 years ago.

\section{Ommatoiulus xerophilus Akkari \& Enghoff, sp. n.}

http://zoobank.org/6C3A27BC-A781-4EF3-B2BD-2275C59126FF

http://species-id.net/wiki/Ommatoiulus_xerophilus

Figs 31-35

Material. Holotype: ${ }^{\lambda}$, W Tunisia, Kasserine Governorate, Châambi National Park, surroundings of the park's guest house, $35^{\circ} 10.139^{\prime} \mathrm{N}, 8^{\circ} 40.486$ 'E, alt. $950-1000 \mathrm{~m}$, scarce trees, Pinus halepensis, Thuja, under stones, logs and in leaf litter, 8.3.2008, P. Stoev \& N. Akkari leg. (ZMUC). Paratypes: 1 $\widehat{0}, 2$ q $q$, W Tunisia, Kasserine Governorate, Châambi National Park, surroundings of the park's guest house, $35^{\circ} 10.139^{\prime} \mathrm{N}, 8^{\circ} 40.486^{\prime} \mathrm{E}$, alt. $950 \mathrm{~m}$, scarce trees, Pinus halepensis, under stones, 7.3. 2008, N. Akkari \& P. Stoev leg. (ZMUC); 2

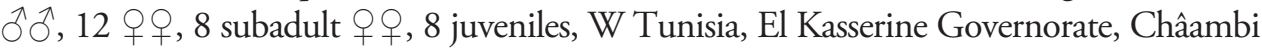


National Park, surroundings of the park's guest house, $35^{\circ} 10.139^{\prime} \mathrm{N}, 8^{\circ} 40.486$ 'E, alt. 950$100 \mathrm{~m}$, scarce trees, Pinus halepensis, Thuja, under stones, logs and in leaf litter, 8.3.2008, P. Stoev \& N. Akkari leg. (ZMUC); 1 ô, 2 우, same data (NMNHS).

Diagnosis. Resembling $O$. chambiensis in the structure of mesomerite, paracoxite, but well distinguished from the latter by the characteristic globular apex of promerite and the shape of solenomerite devoid of a rounded notch.

Etymology. The species name is a Greek adjective referring to the affinity of the species for dry habitats.

Description. Males: L: 15.7-15.9 mm, H: 1.54-1.65 mm, 44-46 PR+1-2 AR+T; females: L: 10.2-23.1 mm, H: 1.44-2.56 mm, 39-46 PR+1-4 AR+T. General colour black to brownish, light brown on the sides; dorsum pale yellow, crossed by thick black mid-dorsal spots. Head dark to blackish with yellow spots in the occipital area, frontal part uniformly black showing yellow spots at antennal level, labral zone yellowish, brighter at margin; antennae brownish. Prozonites blackish with light brownyellowish spots becoming dominant laterally, just below the ozopore line; dorsally pale, with big, irregularly shaped black spots; metazonites predominantly grey-whitish and glossy, legs yellowish. Telson: anal valves dark brown-blackish, with dense yellow sputter, preanal ring blackish sputtered with yellow, dorsal side and caudal projection mostly pale, subanal scale yellowish.

Prozonites with fine striae; metazonites with regular striae, becoming denser laterally, suture complete, curving at the level of ozopores; latter small, rounded, situated on metazonites situated at about their diameter from the suture. Anal valves setose, with 6-7 setae on the surface and numerous submarginal and marginal setae; subanal scale rounded and setose; preanal ring with $1+1$ setae on the sides, protruding in a caudal projection with $3+3$ setae and a small hyaline process on the tip.

Male sexual characters. Mandibular stipites expanded in rounded posterior-ventral lobes, first pair of legs hook-shaped, remaining legs with postfemoral and tibial pads.

Gonopods. Promerite (P) (Figs 31, 32) bent anteriad, not very broad, with parallel margins, mesal ridge $(\mathbf{M})$ broad, distally narrowing and truncate, bearing several serrations (se) and separated from the apical lobe (ap); by an incision; lateral margin mostly rectilinear, only slightly narrowing subapically at the level of the mesal incision; apical lobe globular, with rounded margin, curved laterad; posterior surface with a number of strong setae aligned distally; telopodite remnant inconspicuous.

Posterior gonopod (Figs 31, 33-35): Mesomerite (Ms) similar to O. chambiensis but broader, strongly truncated and distally bent mesad (Figs 33-35); solenomerite (S) broad, with scattered setae on posterior margin, strongly narrowing at mid-length, apical part with a wrinkled blunt lamella $(\mathbf{w l})$ covering a slender and protruding process (ds) housing the distal part of the seminal groove (g) (Figs 31, 33, 35); the latter running from the fovea (F) (Figs 31, 33-35) up to process ds. Paracoxite (Px) broad, curved mesad, emerging from a depressed coxite (Co), distal third slightly enlarged, apically narrowing into a pointed apex, directed mesad (Figs 33-35).

Distribution. Arid bioclimatic zone, central Tunisia; hitherto known only from the type locality, Châambi Mountain.

Habitat. Open areas with scattered Pinus halepensis trees. 

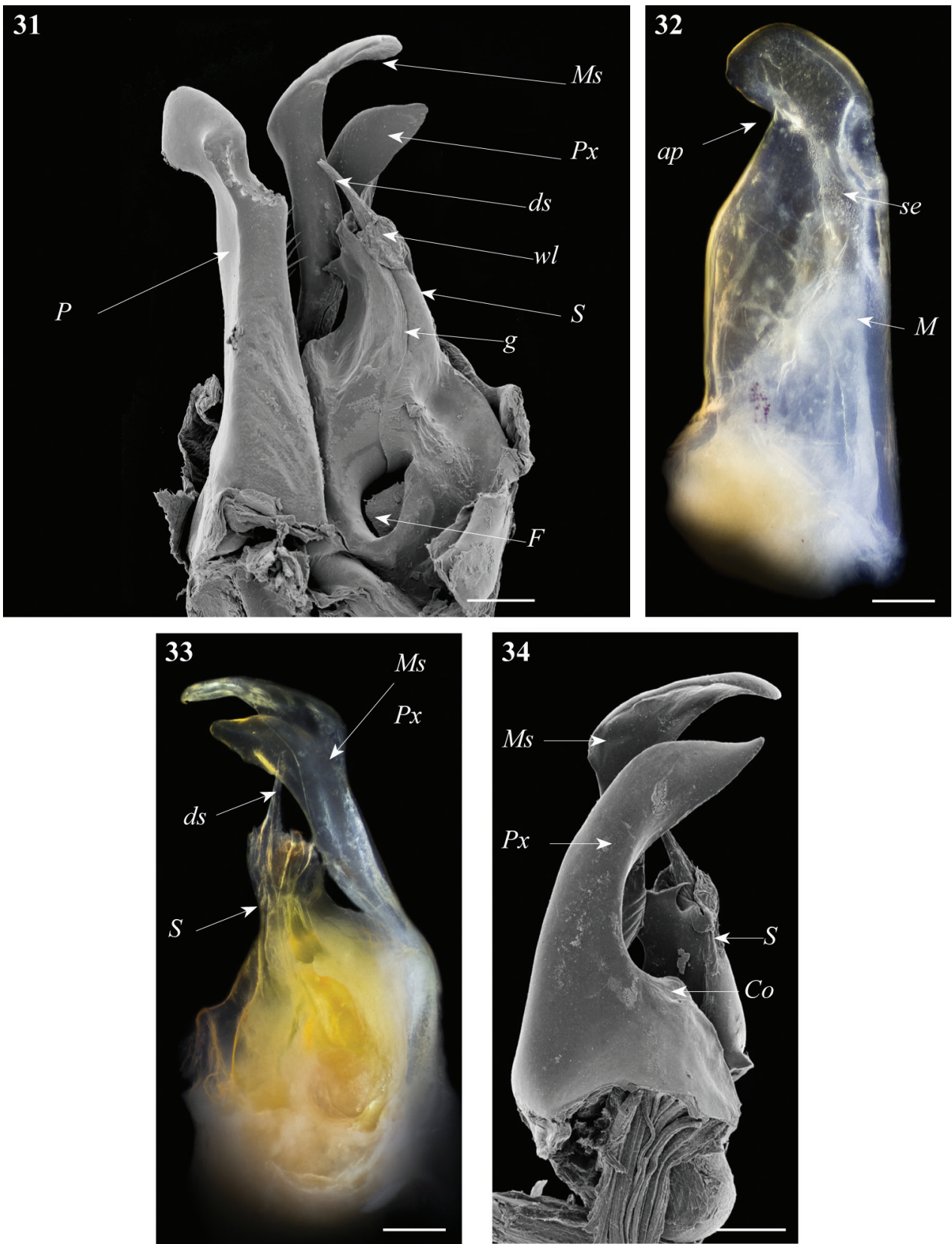

Figures 3 I-34. Ommatoiulus xerophilus sp. n. paratype, gonopod structures. 3 I Left gonopod, mesal view 32 Right promerite, posterior view 33 Right posterior gonopod, mesal view 34 Right posterior gonopod, latero-posterior view. Abbreviations: ap distal process of the promerite, Co coxite, $\mathbf{d s}$ distal process of the solenomerite, $\mathbf{F}$ fovea, $\mathbf{g}$ seminal groove, $\mathbf{M}$ mesal ridge, $\mathbf{M s}$ mesomerite, $\mathbf{P}$ promerite, Px paracoxite, $\mathbf{S}$ solenomerite, se serrations, wl wrinkled lamella. Scale bar: $0.1 \mathrm{~mm}$. 


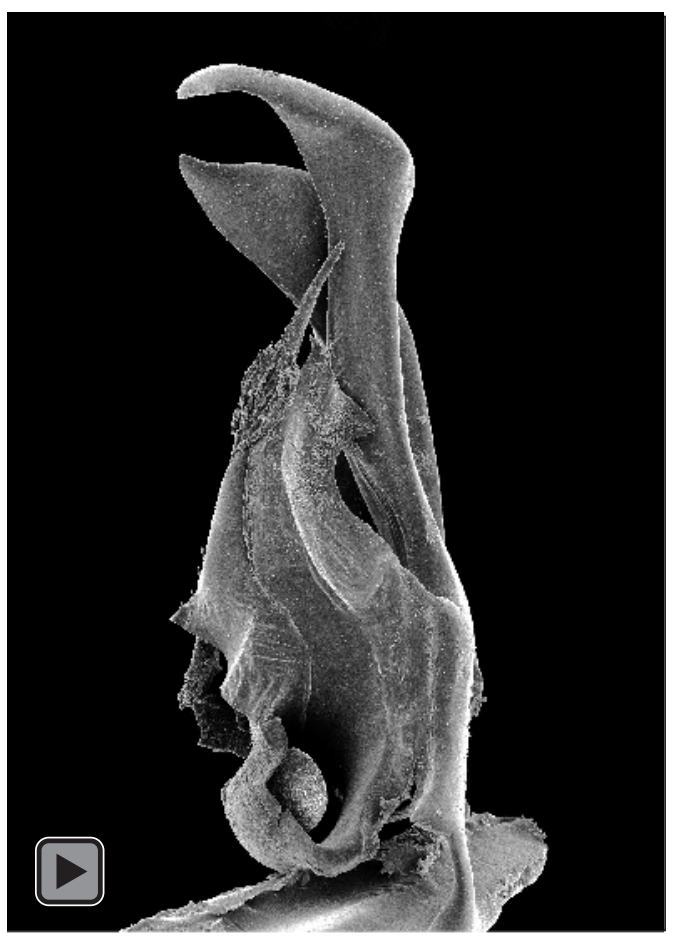

Figure 35. Ommatoiulus xerophilus sp. n. paratype, right posterior gonopod. Interactive SEM image. [Morphbank \# 831246-831263]

\section{Ommatoiulus zaghouani Akkari \& Enghoff, sp. n.}

http://zoobank.org/F23E46BA-1E8C-4B6D-BF46-73D9A37E8E42 http://species-id.net/wiki/Ommatoiulus_zaghouani

Figs 36-39

Material. Holotype: ${ }^{\lambda}$, NE Tunisia, Zaghouan Governorate, Jebel Zaghouan, 36²3'N, $10^{\circ} 06 \mathrm{E}$, alt. 365m, Pinus forest, 13.3.2009, N. Akkari \& H. Enghoff leg. (ZMUC).

Diagnosis. Gonopods resembling those of $O$. seurati but distinguished by a broader distal part of the promerite, a subapical lateral projection on the mesomerite and a much shorter solenomerite.

Etymology. Named after Jebel Zaghouan, the type locality.

Description. Male: L: $28.5 \mathrm{~mm}, \mathrm{H}: 2.56 \mathrm{~mm}, 49 \mathrm{PR}+1 \mathrm{AR}+\mathrm{T}$. General colour alternate dark and light golden brown; dorsum with a thin black axial line. Head dark to blackish, with brownish spots on the frontal part and on the mandibular stipites, labral zone and mouth parts pale, marginally bright yellow; antennae brownish. Prozonites dark to blackish, covered with yellowish spots; metazonites pale brown to whitish laterally and golden brown dorsally, legs yellowish. Telson: anal valves black, preanal ring blackish, caudal projection yellowish, subanal scale yellowish. 

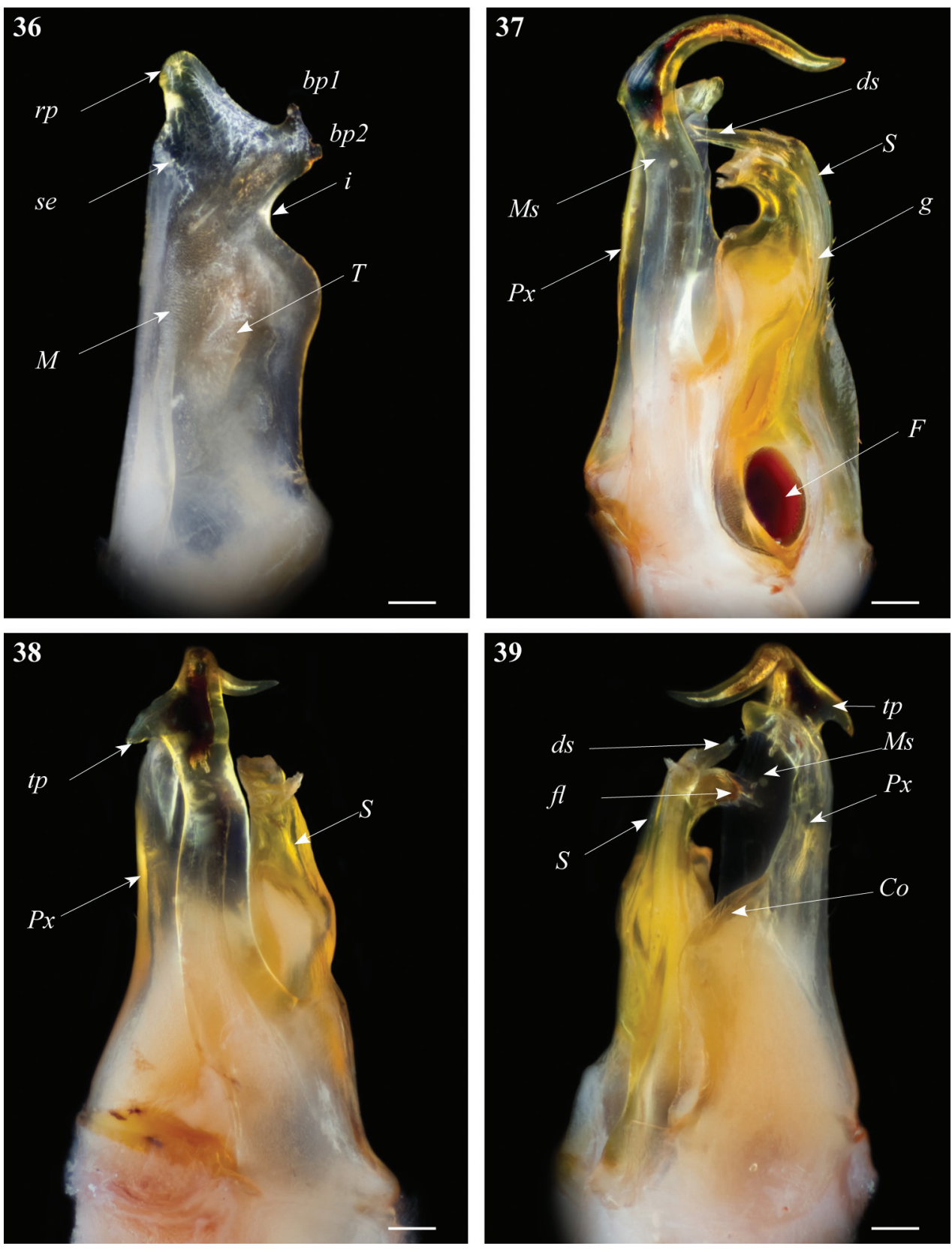

Figures 36-39. Ommatoiulus zaghouani sp. n. holotype, gonopod structures. 36 Left promerite, posterior view 37 Left posterior gonopod, mesal view 38 Left posterior gonopods, anterior view 39 Left posterior gonopods, postero-lateral view. Abbreviations: bp1, bp2: small bumps on the apical lateral process, Co coxite, $\mathbf{d s}$ distal process of the solenomerite, $\mathbf{F}$ fovea, $\mathbf{f}$ folded lamella, $\mathbf{g}$ seminal groove, $\mathbf{M}$ mesal ridge, Ms mesomerite, $\mathbf{i}$ lateral incision on the promerite, Px paracoxite, $\mathbf{r p}$ apical mesal process of the promerite, $\boldsymbol{S}$ solenomerite, se serrated process, tp: triangular distal process. Scale bar: $0.1 \mathrm{~mm}$. 
Prozonites with fine irregular striae; metazonites with regular striae, becoming dense laterally, suture complete, curving at the level of ozopores; ozopores small, rounded, situated in metazonites, situated at about their diameter from the suture. Anal valves setose, with 4-6 setae on the surface, ca 14 submarginal and numerous marginal setae; subanal scale rounded and setose; preanal ring with $2+2$ setae on the sides, protruding in a caudal projection with $(6-7)+(6-7)$ setae on the tip and bearing a small hyaline process.

Male sexual characters. Mandibular stipites expanded in rounded posterior-ventral lobes, first pair of legs hook-shaped, remaining legs with postfemoral and tibial pads.

Gonopods. Promerite (Fig. 36) proximally subrectangular, strongly narrowed distally by a deep incision (i) on the lateral margin; mesal ridge (M) broad, distally protruding in a serrated edge (se); apical part with a mesal triangular blunt process (rp) protruding mesodistad, and a lateral protruding process with two small apical bumps (bp1, bp2); posterior surface of promerite showing few scattered setae near the mesal margin; remnant of telopodite $(\mathbf{T})$ large and ovoid, located at mid-length of the process.

Posterior gonopod (Figs 37-39): Mesomerite (Ms) large, and uniformly broad (Figs 37,38 ) with a distal triangular pointed extension on the lateral margin (tp), distal third strongly curved mesoposteriad and narrowed in a long and slender apical process (Figs 37, 38,39); solenomerite (S) broad, with scattered setae on posterior margin; anteriorly simply rounded devoid of processes; apically with a hyaline folded lamella $(\mathbf{f})$ and a slightly protruding process (ds) housing the distal part of the seminal groove $(\mathbf{g})$; the latter running from the fovea (F) (Fig. 37) up to process ds. Paracoxite (Px) stout and curved apically slightly narrowing into a rounded apex directed mesad, coxite broad (Co) (Fig. 39).

Distribution. Semi-arid bioclimatic zone in northeastern Tunisia; known only from Zaghouan Mountain.

Habitat. Forest dominated by Pinus halepensis.

\section{Updates to the list of Ommatoiulus species in North Africa}

Akkari et al. (2009) summarized all records of julidan millipedes, including Ommatoiulus species, from Tunisia and provided a complete list of the North African members of the order. A number of additions and corrections to the lists are presented here:

- We refute the presence of O. diplurus appendiculatus (Brolemann, 1925) in Algeria. This taxon is based on females and juveniles only, and Akkari and Enghoff (2012) already regarded the presence of O. diplurus (Attems, 1903) in North Africa uncertain.

- The record of O. aumalensis (Brolemann, 1925) from Tunisia by Akkari et al. (2009) was due to a misidentification and actually refers to $O$. fuscounilineatus (Lucas, 1846).

- Ommatoiulus sempervirilis Akkari \& Enghoff, 2011 was described from the Tunisian islands Galita and Zembretta (Akkari and Enghoff 2011). 
- Ommatoiulua chambiensis, O. crassinigripes, O. kefi, O. khroumiriensis, O. xerophilus, O. xenos and $O$. zaghouani spp. n., are described from northern and central Tunisia in the present paper bringing the overall number of Ommatoiulus species in Tunisia to 12, and to 28 in North Africa.

- We refute the presence of O. lapidarius (Lucas, 1846) in Libya. This record was based on the synonymy of Julus rimosus Karsch, 1881 (see Manfredi 1939, Schubart 1952) with O. lapidarius, but re-examination of the holotype of $J$. rimosus (Museum für Naturkunde, Berlin) has shown that this is a valid species (Akkari 2013).

\section{Discussion}

Three of the new Tunisian Ommatoiulus species were found in Châambi Mountain, which is the highest mountain range in Tunisia. The mountain is located only a few kilometres from the Algerian border and in spite of its arid character is known to harbour a number of endemic species (cf. Kovařík 2006, Hartenberger 1986), which is here confirmed by the finding of $O$. chambiensis, O. xerophilus and $O$. crassinigripes spp. n. in semi-arid open habitats of the mountain. With regard to morphology, $O$. chambiensis and $O$. xerophilus show great resemblance in the gonopod structure as they both have apical serrations connecting the mesal ridge of the promerite with the apical processes of the promerite, which is reminiscent of similar structures found in the O. fuscounilineatus species group (see Akkari and Enghoff 2012, figs 94-96). The posterior gonopods of both species are outstanding in having a large, distally curved mesomerite and paracoxite, and a relatively short and simply structured solenomerite. However, clear differences between them were observed in the apex of the promerite: globular and with a blunt margin in O. xerophilus, and subtriangular in O. chambiensis; the paracoxite is apically more rounded in O. chambiensis, while the solenomerite has a notch and a distal pointed process in the latter species. With regard to somatic traits, O. chambiensis and O. xerophilus display differences in colour patterns and body size. O. xerophilus has clear pale dorsal longitudinal stripes which are lacking in $O$. chambiensis. Analysis of the variation of the maximum vertical diameter in relation to the number of podous rings for the different developmental stadia demonstrated that $O$. chambiensis is generally larger (more podous rings, higher body diameter) than $O$. xerophilus (Fig. 40). Of special importance is the fact that the size difference is apparent within each developmental stadium. Thus, $O$. chambiensis males with $8 \mathrm{RO}$ have more podous rings and larger diameter than $O$. xerophilus males with 8RO. The same is true for specimens with $9 \mathrm{RO}$ although the studied material is much smaller.

O. crassinigripes is the only schizophylline millipede collected at more than 1500 $\mathrm{m}$ elevation in Tunisia. However, it occurs also at lower elevation in central Tunisia (El Kef, Thala, Makthar, Kairouan) and is very unlikely to be an alticolous species like Ommatoiulus gravieri (Brolemann, 1924), which is known from 3000-3200 m altitude in Jebel Tachdirt of the High Atlas in Morrocco (Brolemann 1924, Akkari et 


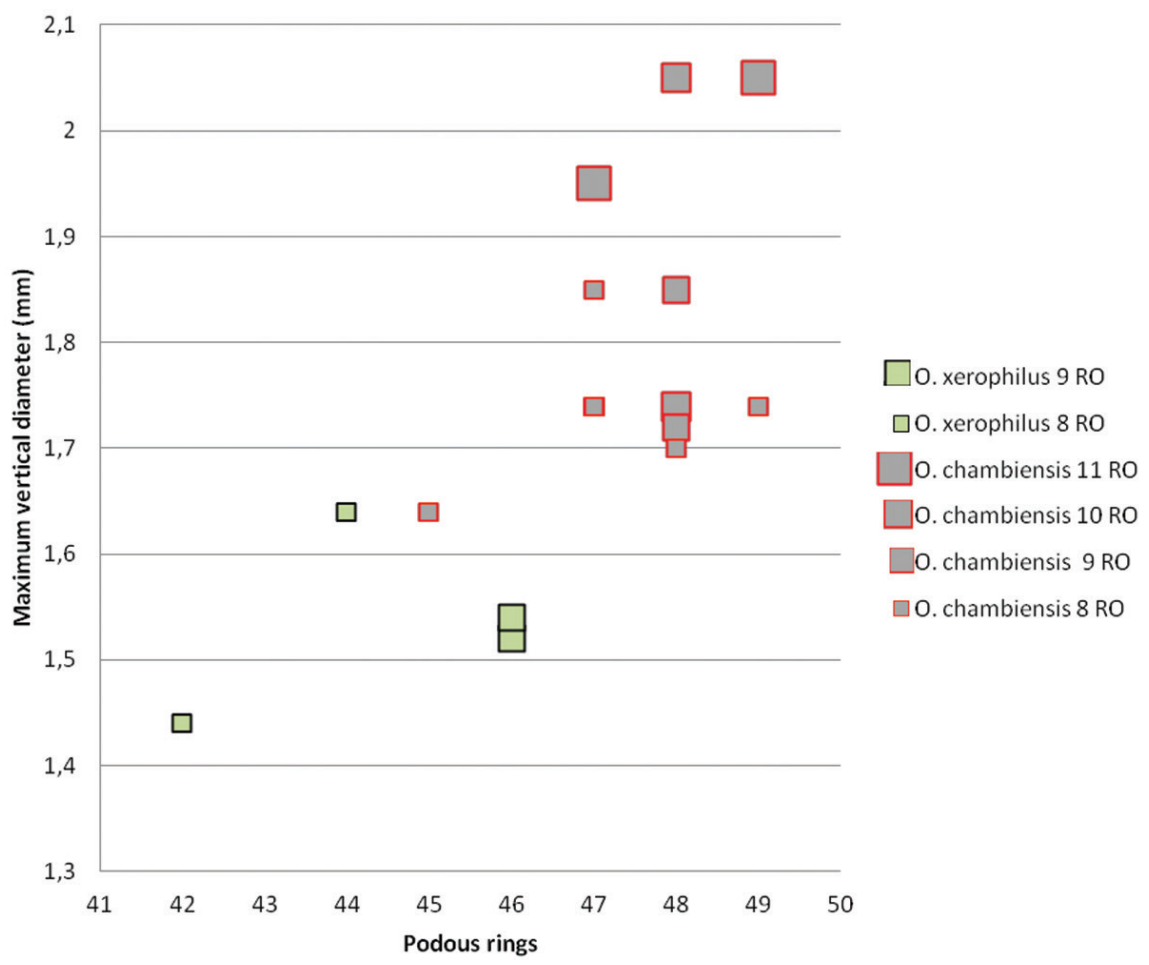

Figure 40. $O$. chambiensis and $O$. xerophilus spp. n. Scatter diagram illustrating size of adult males expressed as maximum vertical body diameter $(\mathrm{mm})$ vs number of podous rings in different developmental stadia (8-11RO).

al. 2009). O. crassinigripes is one of the largest Ommatoiulus species in Tunisia and, together with $O$. khroumiriensis, is the closest to O. punicus with regard to gonopod shape (Fig. 41). The three species, which were all treated under $O$. punicus by Akkari et al. (2009), have quite similar gonopod conformations, yet display a number of constant differences in both promerite and posterior gonopods (Table 1). Although resembling, differences in posterior gonopods can be clearly noticeable on the rotatable models (Figs 13, 26, 41), which, in addition to the external morphological features, indicate their separate taxonomic status. The external morphological differences concern colour pattern and size. Fig. 42 illustrates the variation of the maximum vertical diameter in relation to the number of podous rings. It clearly demonstrates that males of $O$. crassinigripes have more podous rings and are generally thicker compared to males of $O$. punicus and $O$. khroumiriensis of the same development stadium (with the same number of RO). The same applies when one compares males of stadia 9 and $10 \mathrm{RO}$ of $O$. punicus and $O$. khroumiriensis where the latter is clearly thicker. The three species are allopatric in Tunisia and exhibit different habitat preferences. $O$. khroumiriensis is confined to the cork-oak forests of the Khroumirie in the northwest (mainly the Aïn Draham area), O. crassinigripes occurs in open, semi-arid habitats of the centre, in the plain of Kairouan and mountains of the Ridge, while O. punicus 
Table I. Comparison of main gonopod and peripheral structures of $O$. punicus, $O$. crassinigripes and $O$. khroumiriensis.

\begin{tabular}{|c|c|c|c|}
\hline & $\begin{array}{c}\text { O. punicus } \\
\text { (Figs 41, 51-53) }\end{array}$ & $\begin{array}{l}\text { O. crassinigripes } \\
\text { (Figs 7-13) }\end{array}$ & $\begin{array}{l}\text { O. khroumiriensis } \\
\text { (Figs 20-26) }\end{array}$ \\
\hline Gonopod structures & \multicolumn{3}{|c|}{ Similarities } \\
\hline \multirow{3}{*}{ Promerite } & \multicolumn{3}{|c|}{ abruptly narrowing in the distal half-third } \\
\hline & \multicolumn{3}{|c|}{ deep lateral incision } \\
\hline & \multicolumn{3}{|c|}{ mesal ridge protruding in a distal process } \\
\hline Mesomerite & \multicolumn{3}{|c|}{ broad, distally narrowing and hook-shaped } \\
\hline \multirow{4}{*}{ Solenomerite } & \multicolumn{3}{|c|}{ broad, narrowing at mid-length } \\
\hline & \multicolumn{3}{|c|}{ subapical triangular process } \\
\hline & \multicolumn{3}{|c|}{ apical folded lamella } \\
\hline & \multicolumn{3}{|c|}{ long and curved seminal groove } \\
\hline \multirow[t]{2}{*}{ Paracoxite } & \multicolumn{3}{|c|}{ lamellar, folded, marginally serrated } \\
\hline & \multicolumn{3}{|c|}{ Differences } \\
\hline \multirow[b]{2}{*}{ Promerite } & $\begin{array}{l}\text { lateral margin well } \\
\text { rounded }\end{array}$ & lateral margin angular & $\begin{array}{l}\text { lateral margin reduced } \\
\text { and pointed }\end{array}$ \\
\hline & $\begin{array}{c}\text { distal process broad and } \\
\text { triangular }\end{array}$ & $\begin{array}{l}\text { distal process laterally } \\
\text { rounded and bulgy }\end{array}$ & $\begin{array}{c}\text { distal process slender, } \\
\text { slightly expanded laterally }\end{array}$ \\
\hline Mesomerite & $\begin{array}{l}\text { distally slightly broaden } \\
\text { and bearing serrations on } \\
\text { the lateral margin }\end{array}$ & $\begin{array}{l}\text { distally broaden latero- } \\
\text { mesad and bearing } \\
\text { strong serrations on } \\
\text { both margins }\end{array}$ & $\begin{array}{l}\text { distally strongly } \\
\text { constricted and narrowed }\end{array}$ \\
\hline \multicolumn{4}{|l|}{ Solenomerite } \\
\hline Paracoxite & $\begin{array}{l}\text { broad, apical margin } \\
\text { rounded }\end{array}$ & $\begin{array}{l}\text { broader, apical margin } \\
\text { truncate }\end{array}$ & slender, apically tapering \\
\hline \multicolumn{4}{|l|}{$\begin{array}{l}\text { Non gonopod } \\
\text { structures (males) }\end{array}$} \\
\hline $\begin{array}{l}\text { Body vertical } \\
\text { diameter }(\mathrm{mm})\end{array}$ & $1.7-2.7$ & $2.7-3.6$ & $2-2.8$ \\
\hline Podous rings & $43-48$ & $45-53$ & $43-48$ \\
\hline Apodous rings & $1-2$ & $1-2$ & $1-2$ \\
\hline Colour & $\begin{array}{l}\text { ash-grey alternating with } \\
\text { light brown, legs purple }\end{array}$ & $\begin{array}{l}\text { pale grey alternating } \\
\text { with golden brown, } \\
\text { legs black }\end{array}$ & $\begin{array}{l}\text { dark grey alternating with } \\
\text { yellowish brown, legs } \\
\text { yellowish brown }\end{array}$ \\
\hline
\end{tabular}

is mainly distributed around Tunis City, Cap Bon Peninsula and the eastern part of the Ridge viz. Zaghouan Mt. in the north (see Akkari et al. 2009). O. punicus was recorded from Aïn Draham, Tabarka and Nefza, as well as from Kairouan Plain by Akkari et al. (2009). These authors pointed out the variation observed in the material: "Ommatoiulus punicus as currently delimited is quite a variable taxon, and a detailed analysis may well necessitate splitting it into several (sub)species." Our renewed study has corroborated this assumption. Attems $(1903,1926)$ must have been looking at $O$. crassinigripes and $O$. khroumiriensis while recording and illustrating Ommatoiulus punicus. In fact the gonopod drawings he provided left no doubt that what he recorded from Aïn Draham (Attems 1926, figs 240-241) is O. khroumiriensis. On the other hand, the record of O. punicus from unspecified locality in Tunisia (Attems 1903: 144 , figs $77-81$ ) is here referred to as $O$. crassinigripes. 


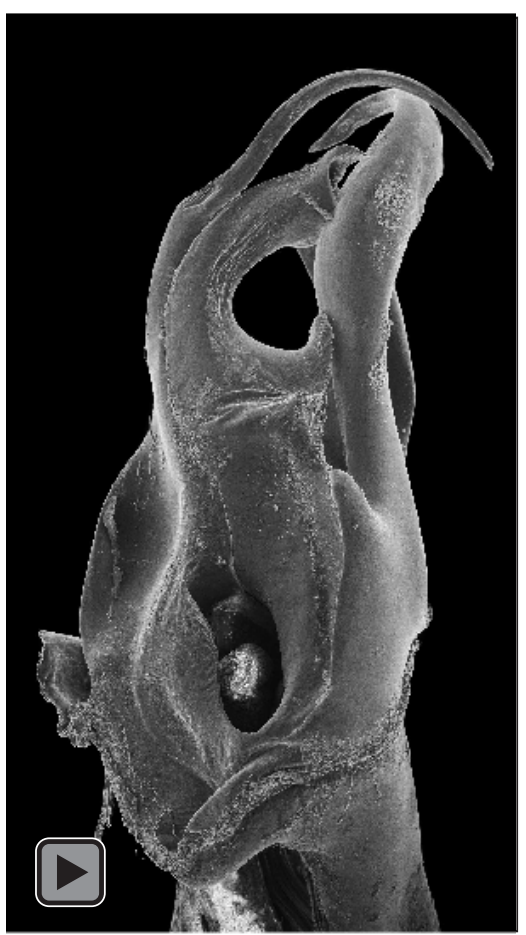

Figure 41. Ommatoiulus punicus, specimen from Jebel Rsas, NE Tunisia, right posterior gonopod. Interactive SEM image. [Morphbank \# 831228-831245]

Intercalary males are here recorded for the species Ommatoiulus khroumiriensis and $O$. crassinigripes. This is of little surprise considering that postembryonic development involving periodomorphosis (regression of secondary sexual characters followed by a return to a morphologically copulatory stadium following an additional moult) is considered as particularly prevalent for schizophylline species (Enghoff et al. 1993). Characteristic morphology of intercalary stadia was directly observed on reared specimens of three schizophyllines: O. moreleti (Lucas, 1860), O. sabulosus (Linnaeus, 1758) and Tachypodoiulus niger (Leach, 1814) while field-collected samples provided periodomorphic specimens belonging to no less than 8 species of genus Ommatoiulus, including O. punicus (see Akkari and Enghoff 2011 for species list). The same authors discussed the particular case of the species $O$. sempervirilis for which a large hand-collected sample revealed the complete absence of intercalary stadia and presence instead of four successive stadia of adult males implying a direct copulatory-copulatory succession (Akkari and Enghoff 2011).

Colour pattern and somatic characters cannot be used reliably to distinguish the $\mathrm{Tu}$ nisian Ommatoiulus species, although we have provided information about these features above in order to point out fine differences between morphologically close or syntopic taxa. In the identification key (below) we prefer to include only gonopod characters. 


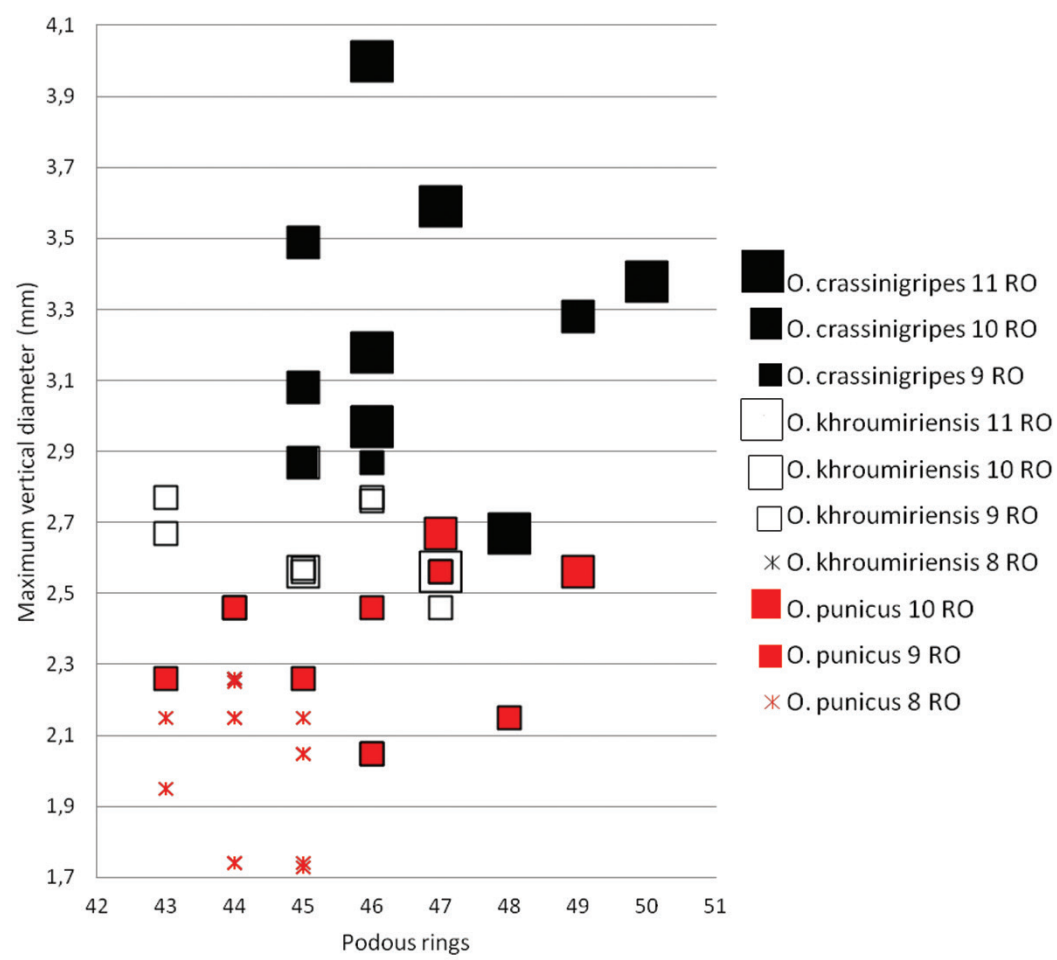

Figure 42. $O$. crassinigripes sp. n., O. khroumiriensis sp. n. and $O$. punicus. Scatter diagram illustrating size of adult males expressed as maximum vertical body diameter $(\mathrm{mm})$ vs number of podous rings in different developmental stadia (8-11RO).

\section{Identification key to Tunisian Ommatoiulus species}

The key is based on characters of the male gonopods.

$1 \quad$ Promerite with parallel margins, apically regularly rounded, without lateral incision (Fig. 43); mesomerite distally expanded into a subrectangular apical plate, concave and mesally incised (Fig. 44)

O. sempervirilis

- $\quad$ Promerite with at least one lateral or apical incision (Figs 2, 7, 14, 20, 32, 45, 47, 49, 51); mesomerite different.......................................................

2 Mesomerite (Ms) apically expanded and bifurcated (Figs 16, 46) ...............3

- $\quad$ Mesomerite (Ms) apically narrowed and simple (Figs 3, 9, 24, 33, 48, $50,53)$

3 Mesomerite (Ms) hammer-shaped (Fig. 46), bifurcated into long asymmetrical processes; promerite (Fig. 45) broad, with a complex distal process, apically bearing two blunt bumps, a pointed process and a lateral serrated lamella ...... 

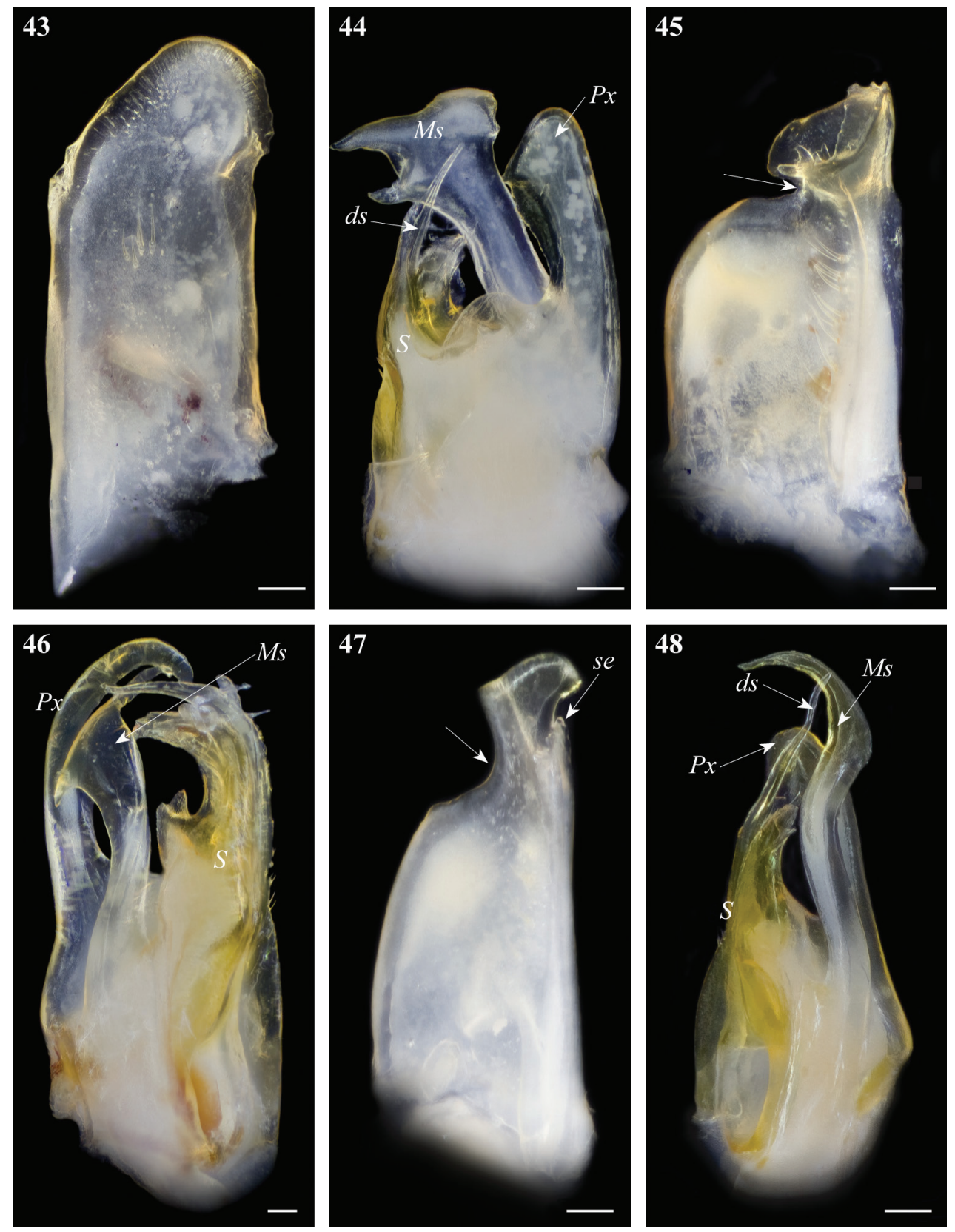

Figures 43-48. Gonopod structures of Ommatoiulus sempervirilis, O. malleatus, O. seurati 43 O. sempervirilis left promerite, posterior view 44 O. sempervirilis, left posterior gonopod, meso-posterior view 45 O. malleatus, right promerite, anterior view 46 O. malleatus, left posterior, mesal view 47 O. seurati right promerite, posterior view $\mathbf{4 8}$ O. seurati, right posterior gonopod, antero-mesal view. Abbreviations: $\mathbf{d} \boldsymbol{s}$ distal process of the solenomerite, $\mathbf{M s}$ mesomerite, Px paracoxite, $\boldsymbol{S}$ solenomerite, se serrations. Arrow pointing to the lateral incision of the promerite. Scale bar $0.1 \mathrm{~mm}$. 
Mesomerite (Ms) horn-shaped (Fig. 16), bifurcated into short and curved processes; promerite (Fig. 14) apically with three lobes separated by deep incisions

Promerite gradually narrowing distally, lateral incision shallow to moderately deep; mesal ridge sometimes protruding in a serrated subapical process (se) (Figs 2, 32, 47); paracoxite (Px) without conspicuous marginal serrations (Figs 5, 34, 48, 50)

Promerite strongly narrowing distally, lateral incision deep; mesal ridge protruding in a blunt subapical process (Figs 7, 20, 51); paracoxite (Px) broad, lamellar, folded, with strong marginal serrations (Figs 8, 22, 52).....

Mesomerite (Ms) slender, sinuous and strongly curved distally; solenomerite (S) with a long distal process (ds) lodging the seminal groove (Fig. 48)..... O. seurati Mesomerite (Ms) broad, distally narrowing; solenomerite $(\mathbf{S})$ with a shorter distal process lodging the seminal groove (Figs 3, 33, 50) Mesomerite (Ms) with irregular margins, apically strongly narrowed and hookshaped; solenomerite $(\mathbf{S})$ with a short distal process (ds) (Figs 37, 50) .......... 7 Mesomerite (Ms) with a regular mesal margin, distally gradually narrowed into a bent folded process; solenomerite $(\mathbf{S})$ with a longer distal process $(\mathbf{d s})$ (Figs 3, 33)

Mesomerite with a subapical serrated lateral process, a truncated mesal margin, apically strongly narrowed into a small hook-shaped process (Fig. $50)$; promerite with a shallow lateral incision and a rounded distal process (Fig. 49).....

O. fuscounilineatus Mesomerite with a subapical lateral process (Figs 37, 39), apically gradually narrowed in a long curved process (Fig. 39); promerite with a deeper lateral incision and a broad distal process with apical and lateral lobes (Fig. 36) ......

O. zaghouani sp. n.

Promerite straight, bearing a pointed distal process (Fig. 27); paracoxite stout and shorter (Fig. 30)

O. xenos sp. $\mathrm{n}$. Promerite strongly bent anteriad, bearing a subapical serrated process (Figs 1, 31); paracoxite broad and elongate (Figs 5, 34).

Solenomerite $(\mathbf{S})$ with a rounded notch $(\mathbf{n})$, a pointed process (pr) and apically a wrinkled protruding lamella (Fig. 5); promerite with a subtriangular apex (Fig. 2). O. chambiensis sp. n.

- $\quad$ Solenomerite $(\mathbf{S})$ without such a process; wrinkled lamella not protruding (Fig. 33); promerite with a globular apex (Fig. 32) O. xerophilus sp. n.

10 Lateral incision of promerite extending basad, distal process broad and triangular (Fig. 20); mesomerite (Ms) distally strongly narrowed, without subapical serrations on lateral margin, paracoxite (Px) slender (Fig. 22) O. khroumiriensis sp. $n$.

- Lateral incision of promerite not extending basad, distal process slenderer and more rounded (Figs 7, 51); mesomerite (Ms) with lateral subapical serrations, paracoxite (Px) broader (Figs 12, 53) 

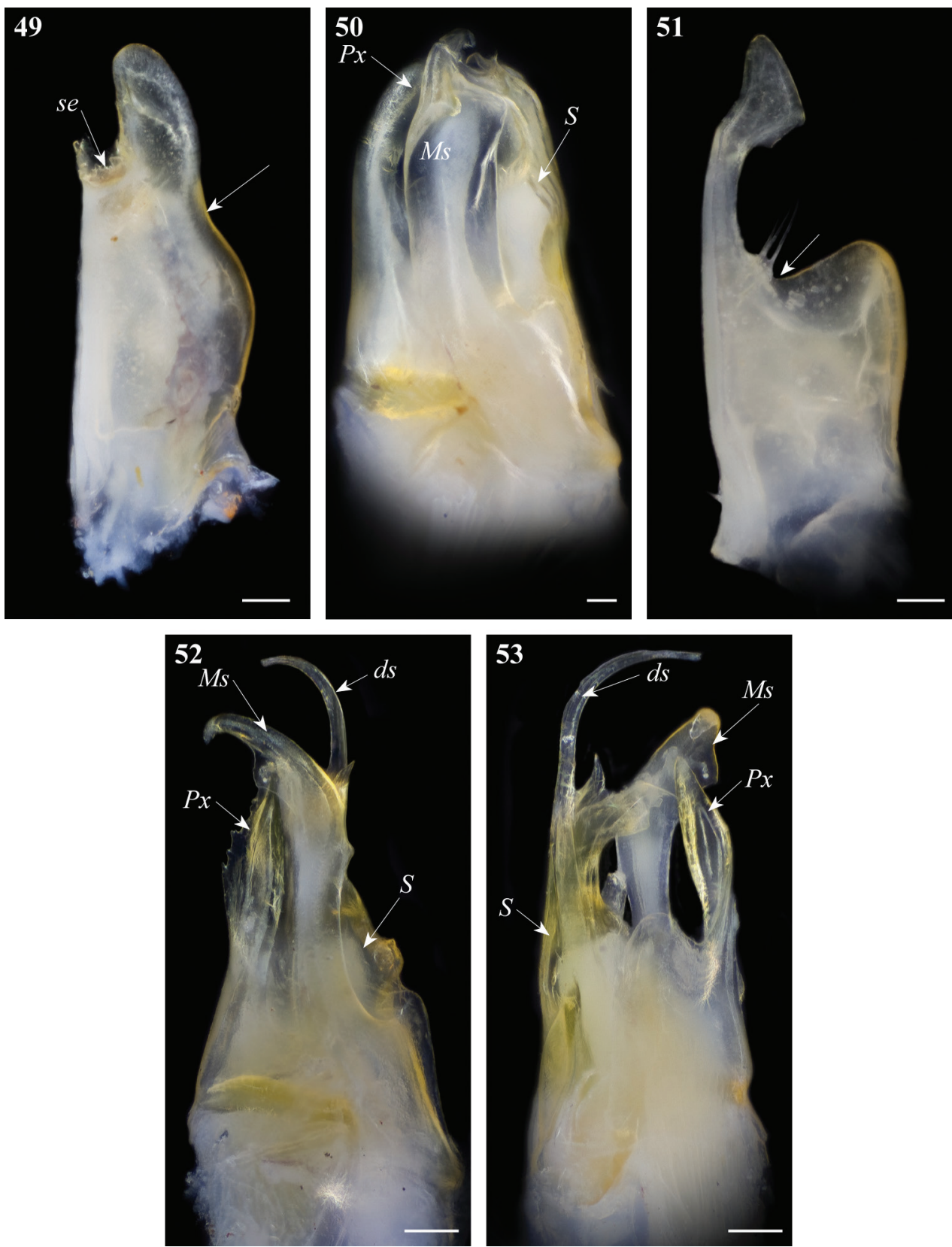

Figures 49-53. Gonopod structures of $O$. fuscounilineatus, O. punicus. 49 O. fuscounilineatus, left promerite, posterior view $\mathbf{5 0}$ O. fuscounilineatus, left posterior gonopod, anterior view $\mathbf{5} \mathbf{I}$ O. punicus, left promerite, posterior view $\mathbf{5 2}$ O. punicus, left posterior gonopod, lateral view $\mathbf{5 3}$ O. punicus, left posterior gonopod, posterior view. Abbreviations: ds distal process of the solenomerite, Ms mesomerite, Px paracoxite, $\mathbf{S}$ solenomerite, se serrations. Arrow pointing to the lateral incision of the promerite. Scale bar $0.1 \mathrm{~mm}$. 
11 Apical process of promerite (ap) bulgy, with a lobed process (ap1) on tip (Fig. 7); mesomerite (Ms) with strong subapical mesal serrations (Fig. 8); paracoxite (Px) broadened distally with truncated apex (Fig. 12)

O. crassinigripes

- Apical process of promerite slender, without a lobed process; mesomerite (Ms) without mesal serrations (Fig. 52); paracoxite (Px) distally narrowed, with rounded apex (Fig. 53)

O. punicus

\section{Interactive key to Tunisian Ommatoiulus species}

We provide an interactive key in Flash (SWF) format to the Ommatoiulus species known from Tunisia. The key is dichotomous and based on gonopod characters. These are illustrated with line drawings, light microscopy photographs and SEMs, and for some of the species with rotatable SEM animations. A species list and species pages are included in the key to provide additional information on species diagnostic characters, distribution and habitats. An introductory section for the first-time user provides background information of importance for applying the key.

Adobe Flash Player (version 11.2 or higher) or a browser (e.g. Internet Explorer, Firefox and Chrome) with Flash Player plug-in is required to run the key.

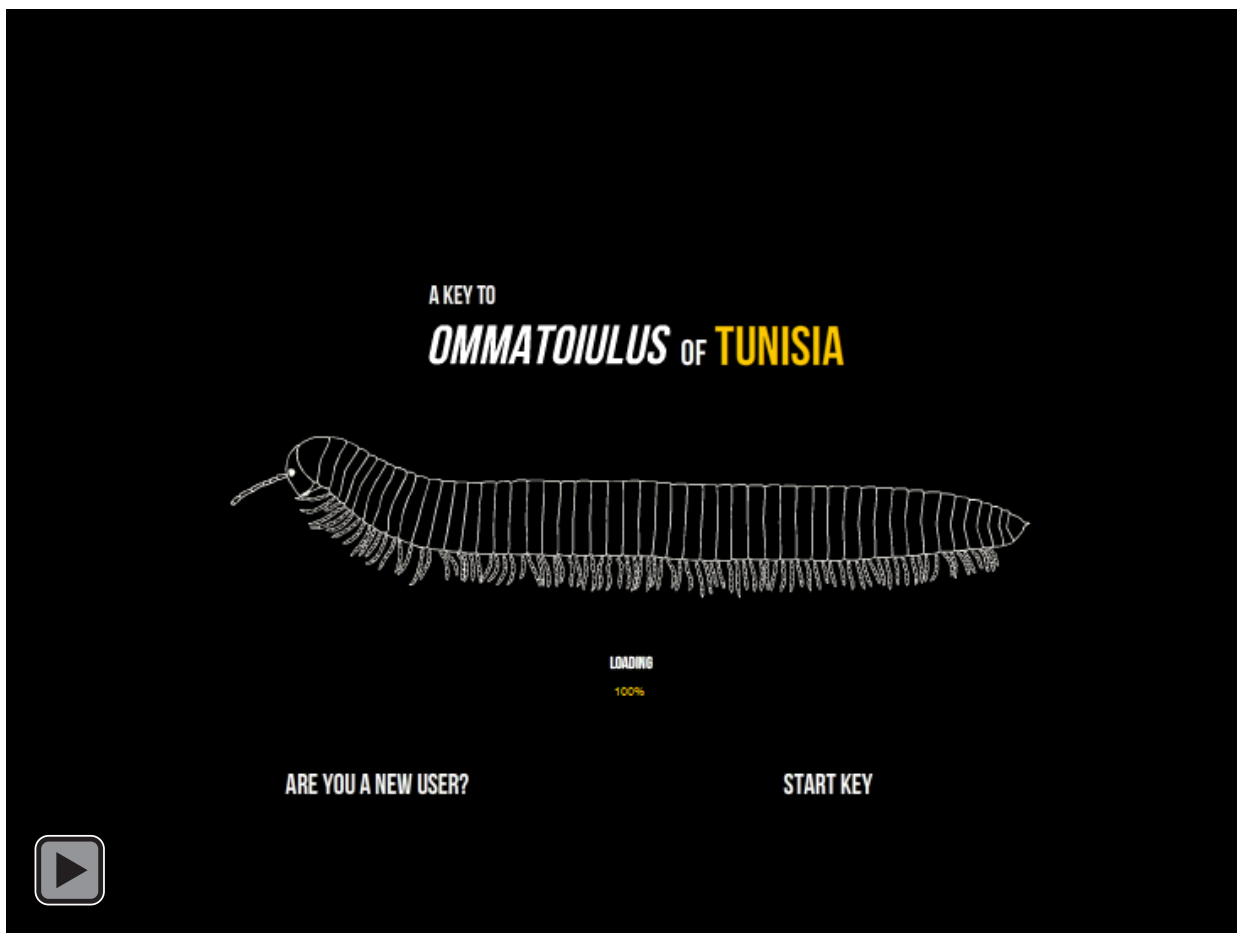




\section{Acknowledgements}

This work was financed by a Carlsberg Foundation grant to N.A. and H.E. We are most grateful to Thomas Pape (ZMUC) for his overall support and comments on the manuscript. Nikolaj Scharff (ZMUC) provided advices about the SEM mounting technique and access to the photographing equipment. Jason Dunlop (Museum für Naturkunde, Berlin), Jean-Jacques Geoffroy (MNHN) and Rosana Pisoni (MSNB) kindly arranged loans under their care. The fieldwork in Tunisia in March 2008 was financed by the Field Museum Collection Fund. N.A. and P.S. are grateful to Petra Sierwald (Chicago, USA) for the logistic help. Specimens were collected in national parks and reserves with a permit from "La direction générale des forêts, ministère d'Agriculture" of Tunisia. NA and PS are thankful to Ridha Ouni and Malek Akkari for their assistance during the filed work. N.A.'s short visit to MNHN, March 2013, was financed by the EC FP7 Project SYNTHESYS. Many thanks are also due to Bob Mesibov (Queen Victoria Museum and Art Gallery, Tasmania) and two anonymous reviewers for their useful comments on the manuscript. The publication of this article was made possible with financial support from the EC FP7 project ViBRANT (www.vbrant.eu) to P.S.

\section{References}

Akkari N (2013) On the identity of Julus rimosus Karsh, 1881 (Diplopoda, Julida, Julidae), the only schizophylline known from Libya (North Africa) and notes on Libyan millipedes. Zootaxa 3652(3): 392-396. doi: 10.11646/zootaxa.3652.3.7

Akkari N, Enghoff H (2011) Copulatory-copulatory male succession and male slenderness in Ommatoiulus sempervirilis sp. n., a new insular millipede from Tunisia (Diplopoda: Julida: Julidae). Journal of Zoological Systematics and Evolutionary Research 49(4): 285-291. doi: 10.1111/j.1439-0469.2011.00625.x

Akkari N, Enghoff H (2012) Review of the genus Ommatoiulus in Andalusia, Spain (Diplopoda: Julida) with description of ten new species and notes on a remarkable gonopod structure, the fovea. Zootaxa 3538: 1-53.

Akkari N, Stoev P, Enghoff H, Nouira S (2009) The millipede order Julida (Myriapoda: Diplopoda) in Tunisia, with an overview of the North African species. Soil Organisms 81 (3): 453-488.

Akkari N, Voigtländer K (2007) Ommatoiulus malleatus sp. n., a new Tunisian millipede, with notes on the punicus species group of Ommatoiulus (Diplopoda, Julidae). Zootaxa 1400: 59-68.

Attems C (1903) Beiträge zur Myriopodenkunde. Zoologische Jahrbücher, Abtheilung für Systematik, Ökologie und Geographie der Thiere 18 (1): 63-154.

Attems C (1926) Myriopoda. In: Kükenthal W, Krumbach T (Eds) Handbuch der Zoologie. Eine Naturgeschichte der Stämme des Tierreiches. 4(1). Progoneata, Chilopoda, Insecta I. Walter de Gruyter and Co., Berlin and Leipzig, 402 pp.

Attems C (1952) Myriopoden der Forschungsreise Dr. H. Franz in Spanien 1951 nebst Übersicht über die gesamte iberische Myriopodenfauna. EOS, Revista Espanola de Entomologia 28(4): 323-366. 
Błażejowski B, Binkowski M, Bitner MA, Gieszcz P (2011) X-ray Microtomography (XMT) of Fossil Brachiopod Shell Interiors for Taxonomy. Acta Palaeontologica Polonica 56 (2): 439-440. doi: 10.4202/app.2010.0114

Bond JE, Sierwald P (2002) Cryptic speciation in the Anadenobolus excises millipede species complex on the island of Jamaica. Evolution 56(6): 1123-1135.

Brolemann HW (1921) Liste des Myriapodes signalés dans le nord de l'Afrique. Bulletin de la Société des Sciences Naturelles du Maroc 1(3-6): 99-110.

Brolemann HW (1924) Myriapodes du Grand Atlas Marocain. Bulletin de la Société des Sciences Naturelles du Maroc, 4(8): 184-197.

Brolemann, HW (1925a) Deux formes nouvelles de Diplopodes tunisiens. Bulletin de la Société d'Histoire Naturelle de l'Afrique du Nord 16: 61-66.

Brolemann HW (1925b) Races nouvelles de Schizophyllum algériens (Myriapodes-Diplopodes). Bulletin de la Société d'Histoire Naturelle de l'Afrique du Nord 16: 245-253.

Cheung DK-B, Brunke AJ, Akkari N, Souza CM, Pape T (2013) Rotational Scanning Electron Micrographs (rSEM): A novel and accessible tool to visualize and communicate complex morphology. ZooKeys 328: 47-57. doi: 10.3897/zookeys.328.5768

Costello MJ, May RM, Stork NE (2013) Can we name Earth's species before they go extinct? Science 339: 413-416. doi: 10.1126/science.1230318

Deans A, Yoder M, Balhoff J (2012) Time to change how we describe biodiversity. Trends in Ecology \& Evolution 27(2): 78-84 doi: 10.1016/j.tree.2011.11.007

Enghoff H (1987) Revision of Nepalmatoiulus Mauriès 1983 - a Southeast Asiatic genus of millipedes (Diplopoda: Julida: Julidae). Courier Forschungsinstitut Senckenberg 93: 241-331.

Enghoff H (1992) Dolichoiulus - a mostly Macaronesian multitude of millipedes. With the description of a related new genus from Tenerife, Canary Islands (Diplopoda, Julida, Julidae). Entomologica Scandinavia 40: 1-158.

Enghoff H, Dohle W, Blower JG (1993) Anamorphosis in millipedes (Diplopoda) - the present state of knowledge with some developmental and phylogenetic considerations. Zoological Journal of the Linnean Society 109: 103-234. doi: 10.1111/j.1096-3642.1993. tb00305.x

Enghoff H, Seberg O (2006) A taxonomy of taxonomy and taxonomists. The Systematist, Newsletter of the Systematics Association 27: 13-15. http://www.systass.org/newsletter/ TheSystematist27.pdf

Enghoff H, Petersen G, Seberg O (2011) Phylogenetic relationships in the millipede family Julidae. Cladistics 27: 606-616. doi: 10.1111/j.1096-0031.2011.00360.x

Erwin T, Penev L, Stoev P, Georgiev T (2012) Accelerating innovative publishing in taxonomy and systematics: 250 issues of ZooKeys. ZooKeys 251: 1-10. doi: 10.3897/zookeys.251.4516

Faulwetter S, Aikaterini V, Michail K, Thanos D, Arvanitidis C (2013) Micro-computed tomography: Introducing new dimensions to taxonomy. ZooKeys 263: 1-45. doi: 10.3897/ zookeys.263.4261

Fontaine B, Perrard A, Bouchet P (2012) 21 years of life shelf between discovery and description of new species. Current Biology 22(22): 943-944. doi: 10.1016/j.cub.2012.10.029 
Frederiksen S, Petersen G, Enghoff H (2012) How many species are there of Pachyiulus? A contribution to the taxonomy of Europe's largest millipedes (Diplopoda: Julida: Julidae). Journal of Natural History 46(9-10): 599-611. doi: 10.1080/00222933.2011.651636

Görög Á, Szinger B, Tóth E, Viszkok J (2012) Methodology of the micro-computer tomography on foraminifera. Palaeontologia Electronica 15(1/3): 1-15. palaeo-electronica.org/ content/issue-1-2012-technical-articles/121-methodology-of-ct-on-forams

Hartenberger J-L (1986) Hypothèse paléontologique sur l'origine des Macroscelidea (Mammalia). Comptes Rendus de l'Académie des Sciences, Paris, 302: 247-249.

Hauser H (2000) Heterodactyly in the genus Craspedosoma (Diplopoda, Chordeumatida): an observation error. 11th international Congress of Myriapdology, 20-24 July 1999, Bialowieza, Poland. Fragmenta faunistica 43: 131-138.

Heim I, Nickel M (2010) Description and molecular phylogeny of Tethya leysae sp. nov. (Porifera, Demospongiae, Hadromerida) from the Canadian Northeast Pacific with remarks on the use of microtomography in sponge taxonomy. Zootaxa 2422: 1-21.

Highton R (2009) Two and a half centuries of Diplopod taxonomy (1758-2008): Retrospect and prospect. In: Roble SM, Mitchell JC (Eds) A Lifetime of Contributions to Myriapodology and the Natural History Museum of Virginia: A Festschrift in Honor of Richard L. Hoffman's 80th Birthday. Virginia Museum of Natural History, Special publication 16, Martensville, VA, 101-108.

Kovařík F (2006) Review of Tunisian species of the genus Buthus with descriptions of two new species and a discussion of Ehrenberg's types (Scorpiones: Buthidae). Euscorpius 34: 1-16.

La Salle J, Wheeler Q, Jackway P, Winterton S, Hobern D, Lovell D (2009) Accelerating taxonomic discovery through automated character extraction. Zootaxa 2217: 43-55.

Manfredi P (1939) Miriapodi della Libia. Bollettino dei Musei di Zoologia ed Anatomia Comparata della R. Università di Torino 47: 109-120.

Pimvichai P, Enghoff H, Panha S (2011a) A revision of the Thyropygus allevatus group. Part 3: the T. induratus subgroup (Diplopoda: Spirostreptida: Harpagophoridae). Zootaxa 2941: 47-68. Pimvichai P, Enghoff H, Panha S (2011b) A revision of the Thyropygus allevatus group. Part 4: the T. cuisinieri subgroup (Diplopoda: Spirostreptida: Harpagophoridae). Zootaxa 2980: 37-48. Schubart O (1952) Diplopoden aus Marokko, gesammelt vom Institut Scientifique Chérifien. Bulletin de la Société des sciences naturelles du Maroc 32(1): 199-225.

Schubart O (1960) Ein weiterer Beitrag zur Diplopoden-Fauna Marokkos. Bulletin de la Société des Sciences Naturelles et Physiques du Maroc 40(3): 159-232.

Schubart O (1963a) Progoneata, Opisthogoneata. In: Brohmer, Eirmann, Ulmer (Eds) Die Tierwelt Mitteleuropas, Bd. II, Leipzig, 51pp.

Schubart O (1963b) Ueber einige Diplopoden aus Algier. Bulletin de la Société des Sciences Naturelles et Physiques du Maroc 43 (1-2): 79-94.

Stoev P, Enghoff H (2011) A review of the millipede genus Sinocallipus Zhang, 1993 (Diplopoda, Callipodida, Sinocallipodidae), with notes on gonopods monotony vs. peripheral diversity in millipedes. ZooKeys 90: 13-34. doi: 10.3897/zookeys.90.1291

Verhoeff KW (1915) Polymorphismus bei Chilognathen und seine Abhängigkeit von äußeren Einflüssen. Zoologischer Anzeiger 45: 378-382, 385-390. 
Verhoeff KW (1916) Beiträge zur Kenntnis der Gattungen Macheiriophoron und Craspedosoma. Zoologischer Jahresarbeit 39: 273-416.

Verhoeff KW (1917) Zur Kenntnis der zoogeographie Deutschlands zugleich über Diplopoden, namentlich Mitteldeutschlands und für die biologische Beurteilung der Eiszeiten. Nova Acta Leopoldina, Halle 103: 1-156.

Verhoeff KW (1939) Über Craspedosomen aus Baden und die Variationen des Craspedosoma germanicum Verh. Entstehung des Polymorphismus. Zoologischer Anzeiger 128: 257-270.

\section{Appendix I}

Source image library of the interactive SEM image of Ommatoiulus chambiensis (doi: 10.3897/zookeys.328.5763.app1) File format: WinZip Image Archive (jpg).

Copyright notice: This dataset is made available under the Open Database License (http://opendatacommons.org/licenses/odbl/1.0/). The Open Database License $(\mathrm{ODbL})$ is a license agreement intended to allow users to freely share, modify, and use this Dataset while maintaining this same freedom for others, provided that the original source and author(s) are credited.

Citation: Akkari N, Cheung DK-B, Enghoff H, Stoev P (2013) Revolving SEM images visualising 3D taxonomic characters: application to six species of the millipede genus Ommatoiulus Latzel, 1884, with description of seven new species and an interactive key to the Tunisian members of the genus (Diplopoda, Julida, Julidae). ZooKeys 328: 5-45. doi: 10.3897/zookeys.328.5763 Source image library of the interactive SEM image of Ommatoiulus chambiensis. doi: 10.3897/zookeys.328.5763.app1

\section{Appendix 2}

Source image library of the interactive SEM image of Ommatoiulus crassinigripes (doi: 10.3897/zookeys.328.5763.app2) File format: WinZip Image Archive (jpg).

Copyright notice: This dataset is made available under the Open Database License (http://opendatacommons.org/licenses/odbl/1.0/). The Open Database License $(\mathrm{ODbL})$ is a license agreement intended to allow users to freely share, modify, and use this Dataset while maintaining this same freedom for others, provided that the original source and author(s) are credited.

Citation: Akkari N, Cheung DK-B, Enghoff H, Stoev P (2013) Revolving SEM images visualising 3D taxonomic characters: application to six species of the millipede genus Ommatoiulus Latzel, 1884, with description of seven new species and an interactive key to the Tunisian members of the genus (Diplopoda, Julida, Julidae). ZooKeys 328: 5-45. doi: 10.3897/zookeys.328.5763 Source image library of the interactive SEM image of Ommatoiulus crassinigripes. doi: 10.3897/zookeys.328.5763.app2 


\section{Appendix 3}

Source image library of the interactive SEM image of Ommatoiulus kefi (doi: 10.3897/ zookeys.328.5763.app3) File format: WinZip Image Archive (jpg).

Copyright notice: This dataset is made available under the Open Database License (http://opendatacommons.org/licenses/odbl/1.0/). The Open Database License $(\mathrm{ODbL})$ is a license agreement intended to allow users to freely share, modify, and use this Dataset while maintaining this same freedom for others, provided that the original source and author(s) are credited.

Citation: Akkari N, Cheung DK-B, Enghoff H, Stoev P (2013) Revolving SEM images visualising 3D taxonomic characters: application to six species of the millipede genus Ommatoiulus Latzel, 1884, with description of seven new species and an interactive key to the Tunisian members of the genus (Diplopoda, Julida, Julidae). ZooKeys 328: 5-45. doi: 10.3897/zookeys.328.5763 Source image library of the interactive SEM image of Ommatoiulus kefi. doi: 10.3897/ zookeys.328.5763.app3

\section{Appendix 4}

Source image library of the interactive SEM image of Ommatoiulus khroumiriensis (doi: 10.3897/zookeys.328.5763.app4) File format: WinZip Image Archive (jpg).

Copyright notice: This dataset is made available under the Open Database License (http://opendatacommons.org/licenses/odbl/1.0/). The Open Database License $(\mathrm{ODbL})$ is a license agreement intended to allow users to freely share, modify, and use this Dataset while maintaining this same freedom for others, provided that the original source and author(s) are credited.

Citation: Akkari N, Cheung DK-B, Enghoff H, Stoev P (2013) Revolving SEM images visualising 3D taxonomic characters: application to six species of the millipede genus Ommatoiulus Latzel, 1884, with description of seven new species and an interactive key to the Tunisian members of the genus (Diplopoda, Julida, Julidae). ZooKeys 328: 5-45. doi: 10.3897/zookeys.328.5763 Source image library of the interactive SEM image of Ommatoiulus khroumiriensis. doi: 10.3897/zookeys.328.5763.app4 


\section{Appendix 5}

Source image library of the interactive SEM image of Ommatoiulus xerophilus (doi: 10.3897/zookeys.328.5763.app5) File format: WinZip Image Archive (jpg).

Copyright notice: This dataset is made available under the Open Database License (http://opendatacommons.org/licenses/odbl/1.0/). The Open Database License $(\mathrm{ODbL})$ is a license agreement intended to allow users to freely share, modify, and use this Dataset while maintaining this same freedom for others, provided that the original source and author(s) are credited.

Citation: Akkari N, Cheung DK-B, Enghoff H, Stoev P (2013) Revolving SEM images visualising 3D taxonomic characters: application to six species of the millipede genus Ommatoiulus Latzel, 1884, with description of seven new species and an interactive key to the Tunisian members of the genus (Diplopoda, Julida, Julidae). ZooKeys 328: 5-45. doi: 10.3897/zookeys.328.5763 Source image library of the interactive SEM image of Ommatoiulus xerophilus. doi: 10.3897/ zookeys.328.5763.app5

\section{Appendix 6}

Source image library of the interactive SEM image of Ommatoiulus punicus (doi: 10.3897/zookeys.328.5763.app6) File format: WinZip Image Archive (jpg).

Copyright notice: This dataset is made available under the Open Database License (http://opendatacommons.org/licenses/odbl/1.0/). The Open Database License $(\mathrm{ODbL})$ is a license agreement intended to allow users to freely share, modify, and use this Dataset while maintaining this same freedom for others, provided that the original source and author(s) are credited.

Citation: Akkari N, Cheung DK-B, Enghoff H, Stoev P (2013) Revolving SEM images visualising 3D taxonomic characters: application to six species of the millipede genus Ommatoiulus Latzel, 1884, with description of seven new species and an interactive key to the Tunisian members of the genus (Diplopoda, Julida, Julidae). ZooKeys 328: 5-45. doi: 10.3897/zookeys.328.5763 Source image library of the interactive SEM image of Ommatoiulus punicus. doi: 10.3897/ zookeys.328.5763.app6 


\section{Appendix 7}

Source file library of the interractive key to genus Ommatoiulus in Tunisia (doi: 10.3897/zookeys.328.5763.app7) File format: WinZip Archive (zip).

Copyright notice: This dataset is made available under the Open Database License (http://opendatacommons.org/licenses/odbl/1.0/). The Open Database License $(\mathrm{ODbL})$ is a license agreement intended to allow users to freely share, modify, and use this Dataset while maintaining this same freedom for others, provided that the original source and author(s) are credited.

Citation: Akkari N, Cheung DK-B, Enghoff H, Stoev P (2013) Revolving SEM images visualising 3D taxonomic characters: application to six species of the millipede genus Ommatoiulus Latzel, 1884, with description of seven new species and an interactive key to the Tunisian members of the genus (Diplopoda, Julida, Julidae). ZooKeys 328: 5-45. doi: 10.3897/zookeys.328.5763 Source file library of the interractive key to genus Ommatoiulus in Tunisia. doi: 10.3897/ zookeys.328.5763.app7 